\title{
Legal Perception and Finance: The Case of IPO Firm Value
}

\author{
Gerhard Schnyder (1D, ${ }^{1}$ Anna Grosman (1D, ${ }^{1}$ Kun Fu (D), ${ }^{1}$ Mathias Siems (D) ${ }^{2}$ \\ and Ruth V. Aguilera (10 ${ }^{3}$
}

${ }^{1}$ Loughborough University London, 3 Lesney Avenue, London, E20 3BS, UK, ${ }^{2}$ European University Institute, Via Bolognese 156, Firenze, 50139, Italy, and ${ }^{3}$ D'Amore-McKim School of Business, Northeastern University, 360 Huntington Avenue, Boston, MA, 02115, USA

Corresponding author email: g.schnyder@lboro.ac.uk

\begin{abstract}
In this paper, we contribute to the literature on institutional determinants of IPO valuation. We introduce the concept of 'legal signalling', which focuses on the perception of the quality of law and thus complements the existing institutional approaches to IPO valuation which consider the quality of the positive law ('standard view') and firm-level corporate governance practices ('firm signalling view'). Our approach explicitly models the difference between the effect of the positive law and the effect of the perception of law on IPO value. Based on a worldwide longitudinal dataset of IPO performance across a large number of countries, we find strong support for the claim that the perception of the quality of law is more important than its actual quality to explain post-IPO firm value. This effect holds regardless of whether the law's quality is correctly perceived or misperceived. Overall, our findings underscore the need for a more sophisticated theorization of the ways in which law affects entrepreneurial finance.
\end{abstract}

\section{Introduction}

A large literature on initial public offerings (IPOs) has focused on the way governance mechanisms influence IPO performance. For example, it has been found that venture capital (VC) syndicates, the presence of foreign venture capitalists or

We are grateful to the editors of this special section, in particular Geoffrey Wood, Pawan Budhwar and Douglas Cumming, for their comments and guidance throughout the process. We would also like to thank Martin Petrin, our discussant during the Entrepreneurial Finance Paper Development Workshop in Honour of Mike Wright, 20-21 June 2020, as well as Mario Daniele Amore, Giovanni Cerulli and Pasquale Scaramozzino for their helpful and constructive comments on earlier drafts. We also acknowledge feedback from the participants to the 2020 International Corporate Governance Society conference. Finally, we thank two anonymous reviewers for their comments. Gerhard Schnyder acknowledges the generous support of the Economic and Social Research Council (ESRC) under project number RES-061-25-0518 (Law \& Agency project). prestigious investment bankers as underwriters and private equity (PE) owners of the IPO firm can constitute firm-level signals that have a positive impact on IPO value (Brav and Gompers, 2003; Chahine, Goergen and Saade, 2021; Coakley, Hadass and Wood, 2007; Jelic, Saadouni and Wright, 2005). Extant studies have also noted that firm valuation at IPO cannot be considered in isolation of institutional factors at the country level (Bell, Filatotchev and Aguilera, 2014; Filatotchev, Jona and Livne, 2020; Gu et al., 2019).

For the specific case of foreign IPOs, some of the existing literature hints at the possibility that the misperception of a country's institutions may also matter. Filatotchev, Jona and Livne (2020) show that IPO companies from home countries with purportedly strong institutions engage more in earnings management than IPO companies from countries with weak institutions. We also know that the latter seek to compensate for weak country-level institutions by building reputational capital through good governance practices. This 
'reputational bonding' or firm-level signalling effect through firm-level practices and strategies involving reputational intermediaries such as banks, institutional investors and boards of directors is well studied (Siegel, 2005). Conversely, firms from countries with purportedly strong legal and regulatory institutions such as the USA may hide behind the good reputation of the country's institutions independently of their actual impact on earnings management (Filatotchev, Jona and Livne, 2020). This suggests that a country's strong institutional reputation may mask the fact that these institutions do not deter firms from engaging in earnings management. This, in turn, implies that the reputation of a country's law may be overly positive compared to its actual effect on firm-level practices.

Yet, while the link between the 'positive law' (i.e. the actual quality of country-level legal institutions), its perception and firm practices is key to this literature, existing studies do not explicitly conceptualize or measure the key distinction between the actual law and its perception. Rather, they implicitly assume a close fit between the quality of the actual law and its perception. This is the case even when the importance of perception (Bell, Filatotchev and Aguilera, 2014) and deviation of firm corporate governance practices from legal rules are acknowledged (Filatotchev, Jona and Livne, 2020; Gu et al., 2019). This neglect, in turn, blurs the lines between two different institutional effects linking laws and IPO valuation, namely, the signalling effect and the actual effect of law on shareholder protection and hence on firm valuation. Indeed, Aguilera and Cuervo-Cazurra (2004) show that regulations - and by extension laws can have two distinct effects: they can increase the actual efficiency of the corporate governance system (which we label the efficiency effect) or increase a country's reputation by signalling the presence of best practices.

In this paper, we seek to fill a gap in the corporate finance literature by more clearly distinguishing the efficiency and the signalling effects of law and thereby explicitly conceptualizing the relationship between the actual quality of the law, its perception and firm practices. We apply this insight to all IPOs that take place in a particular jurisdiction (i.e. in contrast to the previous literature, we do not limit our analysis to foreign IPOs). Specifically, we focus on IPO value, which has proven to be a fruitful empirical terrain to study perception
(Bell, Filatotchev and Aguilera, 2014; Filatotchev, Jona and Livne, 2020). For this purpose, we are interested in the general perception of a country's shareholder protection laws - which we call 'legal perception' - rather than in the perception of these laws by investors. Our concept of 'legal perception' thus seeks to capture a country's 'legal reputation' in terms of shareholder protection, which is a broader phenomenon than the assessment of the legal quality of the law by investors.

In sum, we explicitly distinguish two different effects of the law on IPO value and investigate how they interact with corporate governance practice. Specifically, we seek to answer three interrelated research questions: Does the law or its perception matter more for IPO firm value? How does misperception of law affect IPO value? How do corporate governance practices impact the relationship between the perception of law and IPO value?

We thus contribute to the Law and Finance literature, which recognizes the importance of law, but often adopts an under-theorized and superficial conceptualization of its impact on economic outcomes (reviewing this literature: Deakin et al., 2017; Schnyder, Siems and Aguilera, 2018). This literature generally assumes a close alignment between law and its perception, and therefore only includes measures of actual law in the analysis. Yet, legal scholarship highlights that there are often misconceptions about basic legal rules, for example, creditor rights (Colby and Ryznar, 2019) or the applicable rules of criminal procedure (Nelken, 2016). In the commercial sphere too, legal misperception is a widespread phenomenon. With respect to corporate and labour law, legal scholars show that the effects of the law are often difficult to predict and particularly to quantify (Petrin, 2016), and that firms misperceive or ignore legal factors such as legal labour protection (Pierre and Scarpetta, 2006). Other studies uncover that firms can strategically use the discrepancy between law and its perception. For example, studies of the Canadian market for incorporation reveal that to benefit from a positive perception effect of federal law, firms reincorporate under federal law even when the provincial law is not substantively different (Cumming and MacIntosh, 2000, 2002). These findings underscore that positive law and its perception often diverge.

We also go beyond prior IPO literature by examining the relevance of perception of the 
quality of law for both domestic and foreign IPOs using a world-wide longitudinal dataset of IPO performance across a large number of countries. Our novel conceptualization of the legal signalling effect thus allows us to contribute both to the comparative IPO literature (Akyol et al., 2014; Engelen and van Essen, 2010) and the still ill-understood question of the role of law in financial markets (Cumming, Schmidt and Walz, 2010; Licht and Adams, 2019; Schnyder, Siems and Aguilera, 2018) by providing a more fine-grained understanding of how the law affects economic outcomes in a comparative context. It also extends Mike Wright's research on entrepreneurial finance in the international context (Cumming et al., 2019; Estrin et al., 2019; Meuleman et al., 2017), institutional theory development (Fini et al., 2017; Hoskisson et al., 2013; Wood, Phan and Wright, 2018), IPOs and corporate governance (Chahine et al., 2019; Fattoum-Guedri, Delmar and Wright, 2018; Filatotchev, Wright and Bruton, 2017) and the increasing internationalization of financial markets (Wood and Wright, 2013, 2015), to whom the special section on entrepreneurial finance in which this paper features is dedicated.

\section{Theoretical background and hypotheses}

\section{IPOs and institutions}

The IPO literature has focused much attention on the factors that determine IPO (under)pricing (Bhagat, Lu and Rangan, 2019). Firm-level factors and managerial motivations (Kim and Weisbach, 2008) have been identified as driving the decision to go public and affecting offering price and valuation (Bhagat, Lu and Rangan, 2019). In addition, country-level institutional factors have increasingly been included as determinants of IPO performance for these firm-level factors (Engelen and van Essen, 2010). In the context of the increasing internationalization of capital markets (Wood and Wright, 2013, 2015), crossnational institutional differences have become an important research focus. Thus, compared to the US market, different national institutions provide different price-setting mechanisms (Derrien and Womack, 2003) and impact the number and type of shares sold (Chahine, 2008).

For our purpose, particularly important are the debates around the so-called 'bonding hypothe- sis' - which holds that by listing in a country with stronger shareholder protection rights, firms can bind themselves to higher governance standards. Proponents of the bonding hypothesis (Coffee, 1999; Karolyi, 2012; Stulz, 1999) would expect a company's home country to weigh a lot less once a company lists in a country with strong legal shareholder protection. Yet, recent studies challenge 'this hypothesis' and sustain that, even in a global economy, home country institutions continue to dominate the perception of the firm in the host market (cf. Karolyi, 2012).

The debate around the bonding hypothesis while specific to the question of foreign listings is revealing regarding the broader question of the impact of legal factors on financial outcomes. The initial formulations of the bonding hypothesis suggested that exposure to stronger legal rules accounts for the positive impact on firm valuation (Coffee, 1999; Stulz, 1999). This mechanism crucially hinges on the assumption that legal rules are fully enforced. Yet, enforcement of laws against foreign issuers is not always as strong as assumed. Enforcement action by public regulators such as the US SEC against foreign issuers is lower than against comparable domestic firms (Licht, 2003; see also Pinegar and Ravichandran, 2010). Therefore, listing on a foreign stock exchange can also be a way to circumvent home country legal requirements while benefitting from reduced enforcement overseas.

Consequently, attention has shifted to measuring the enforcement of legal rules by regulators (Coffee, 2007) and through private litigation (Gande and Miller, 2012). This literature acknowledges possible discrepancies between the 'law in the books' and the 'law in action' (i.e. their enforcement). Yet, even this line of research is still based on the standard assumption of the Law and Finance literature that for any given level of enforcement there is no discrepancy between the perception of laws and the actual quality of the law. That is, it is assumed that the level of enforcement is known and accounted for when law is perceived. In this paper, we question this assumption and seek to explicitly distinguish the perception of law and positive law as two distinct constructs. The following section discusses how this distinction is theoretically justified by a more nuanced view of the role of law for economic outcomes than the standard view acknowledges. 


\section{Law and Finance}

A large literature in the area of Law and Finance contends that firm-level governance - and hence financial outcomes - may depend on the legal environment in which the firm is embedded (Deakin, Sarkar and Siems, 2018; Djankov et al., 2003; La Porta, Lopez-de-Silanes and Shleifer, 2008; La Porta et al., 1998). The importance of law has also been acknowledged in studies on IPOs (Akyol et al., 2014; Engelen and van Essen, 2010).

The Law and Finance literature is dominated by a rational approach to the effect of law, which draws on the classical theory of legal positivism as well as transaction cost economics theory (for critical reviews, see Deakin et al., 2017; Milhaupt and Pistor, 2008; Schnyder, Siems and Aguilera, 2018). The rational paradigm suggests that law's role in the economy is essentially a functional onemostly one of reducing opportunism and securing property rights - and institutions (including laws) are seen as consciously designed problem-solving devices (Chisholm, 1995). This suggests a specific mechanism by which law deploys its effect on economic actors, namely, the law creates incentives for actors to comply with it based on efficiency considerations related to cost-benefit analysis of compliance versus non-compliance (Becker, 1968).

Following Milhaupt and Pistor (2008), we call this rational perspective the standard view. It implies that corporate practice closely matches legal rules (i.e. that corporate governance 'deviance' Aguilera, Judge and Terjesen, 2016 - is low, at least when controlling for the strength of law enforcement and for the relationship between punishment and rewards for breaking the law). Rational actors will follow legal prescriptions if and only if the punishment for not doing so outweighs the expected benefits from infringing the law. The accuracy of this assumption has been discussed extensively in previous studies (Aguilera and Williams, 2009; Milhaupt and Pistor, 2008; Schnyder, Siems and Aguilera, 2018).

Another implication of the standard view has received much less attention, namely the assumption that, as rational actors, economic actors will correctly assess the actual quality of a country's law. Even research acknowledging the importance of perception implicitly adheres to the positivist view by using measures of the actual content of the positive law as a proxy for perception (Bell, Filatotchev and Aguilera, 2014).
We move away from a legal positivist view and explicitly introduce the distinction between the positive law (or 'actual law') and its perception. Such a distinction is particularly important concerning certain measures of firm performance. Thus, while rational accounts of the law certainly capture part of the reality, because certain firmlevel outcomes may mainly be affected by the impact of law on efficiency (e.g. measures of output), others may depend more on subjective factors. In particular, firm valuation is by its very nature a subjective factor that depends more on actors' perception than any objective reality of the law.

To account for this, rational accounts of institutional factors have been complemented by more sociological views, which stress that organizations and countries (through their governments/lawmakers) may adopt certain rules, not for reasons of technical efficiency (in our case to protect shareholder rights), but rather to comply with social expectations and needs for social legitimation by following a 'logic of appropriateness' (Aguilera and Cuervo-Cazurra, 2004; DiMaggio and Powell, 1983). A large literature has investigated the symbolic adoption of expected norms and rules by economic actors, which can differ widely from actual practices (e.g. Westphal and Zajac, 1994). Applied to country-level law, such instances of 'decoupling' (Bromley and Powell, 2012) imply that the laws on the books and the laws in practice may be very different. Conversely, this view also suggests that the impact of the law on behaviours may not depend on enforcement alone. In many cases, laws can have an effect even when they are not enforced, because they signal appropriate behaviour and actors follow them due to normdriven behaviour (Deakin et al., 2017; Schnyder, Siems and Aguilera, 2018).

This perspective is supported by a growing sociological and behavioural literature in legal studies. We call the latter view the legal signalling view, where laws deploy their effect on behaviours and economic outcomes through normative signals of appropriate behaviour. Such signals, of course, are subjective in the sense that each addressee of the law may perceive the legal signals in different ways. A further important empirical implication of the legal signalling view is therefore that the perception of the law is as important as its actual content. While the actual content can explain the 'efficiency effect' of law on economic activity (e.g. 
minority shareholder protection reducing transaction costs), perception may explain outcomes that are determined by subjective positions. Firm valuation is one such outcome. Consequently, the alignment of the objective quality of shareholder protection in the law and its perception by economic actors cannot be taken for granted but may be an empirical question.

The importance of perception and signalling is also acknowledged by a third view, the firm signalling view, which holds that firms can compensate for weak legal shareholder protection by adopting corporate governance practices that go beyond the legal requirements (e.g. Bell, Filatotchev and Aguilera, 2014; Khanna and Palepu, 2004).

The so-called 'nested legitimacy' perspective combines these two signalling approaches. It holds that firm-level signals aiming to increase firm legitimacy in the host country through good corporate governance practices overlap with signals emanating from the home regulatory environment (Bell, Filatotchev and Aguilera, 2014). Yet, while the nested legitimacy approach accounts for the role of perception and signals for IPO performance, existing studies do not distinguish - either conceptually or empirically - the perception of law from the positive law. In other words, it is assumed that it is the actual content of the law - not its perception that will impact IPO valuation. This assumption is in turn based on the above-mentioned standard view of the law, which assumes that the actual quality of legal shareholder protection does not differ from its perception. By contrast, we apply the sociological view not only to firm-level signals but also to 'legal signals'. Therefore, we expect the quality of law to be less important for firm valuation than its perception. Indeed, economic actors may misperceive the law in any given country and base their decisions on their perception and not necessarily a correct assessment of the content of that law. Therefore, we argue that regardless of the actual quality of a country's law, the value of IPOs will be driven - ceteris paribus - by the perception of legal shareholder rights protection. Thus, our first hypothesis is:

H1: The value of IPOs is positively associated with the perception of legal shareholder protection, such that the more positive the perception, the higher the value of IPOs.
However, beyond this proposed direct effect of perception on IPO value, our approach raises the important question of the underlying relationship between the impact of the positive law and the perception of the law on IPO value. In other words, we seek to uncover whether the 'efficiency effect' or the 'signalling effect' dominates. Both the 'standard view' and the 'legal signalling' view may capture part of the effect of the law on economic outcomes. Whether positive perception outweighs low legal quality and whether negative perception outweighs high legal quality (or vice versa) may ultimately be an empirical question. This can be investigated in cases where the quality of the law and the perception of the law are not aligned (i.e. where strong legal shareholder protection is perceived as weak and vice versa). Indeed, as explained above, the legal signalling view acknowledges that there can be discrepancies between the actual quality of law and its perception. Based on the sociological approach that underscores the importance of social valuation, we hypothesize that it is the perception rather than the positive law that dominates IPO value in cases of misperception of the law:

$H 2 a$ : When the quality of law is high but misperceived, the positive impact of the perception of law on the value of IPOs is attenuated compared to when it is correctly perceived.

$H 2 b$ : When the quality of law is low but misperceived, the positive impact of the perception of law on the value of IPOs is enhanced compared to when it is correctly perceived.

Finding support for these hypotheses would imply that the signalling effect dominates the efficiency effect of law.

Challenging the strong link between law and practice that underpins the standard view also means that firm-level practices under any given law become an important topic for empirical investigation, as they can 'deviate' from legal rules (Aguilera, Judge and Terjesen, 2016), either by falling short of legal standards or going beyond them. The 'firm signalling view' suggests that in countries with negatively perceived law, firm-level corporate governance practices can compensate for the negative perception of the law - independently of the quality of the positive law (Bell, Filatotchev and Aguilera, 2014; Khanna and Palepu, 2004). Yet, for firms from countries where the law is positively perceived, adopting corporate 


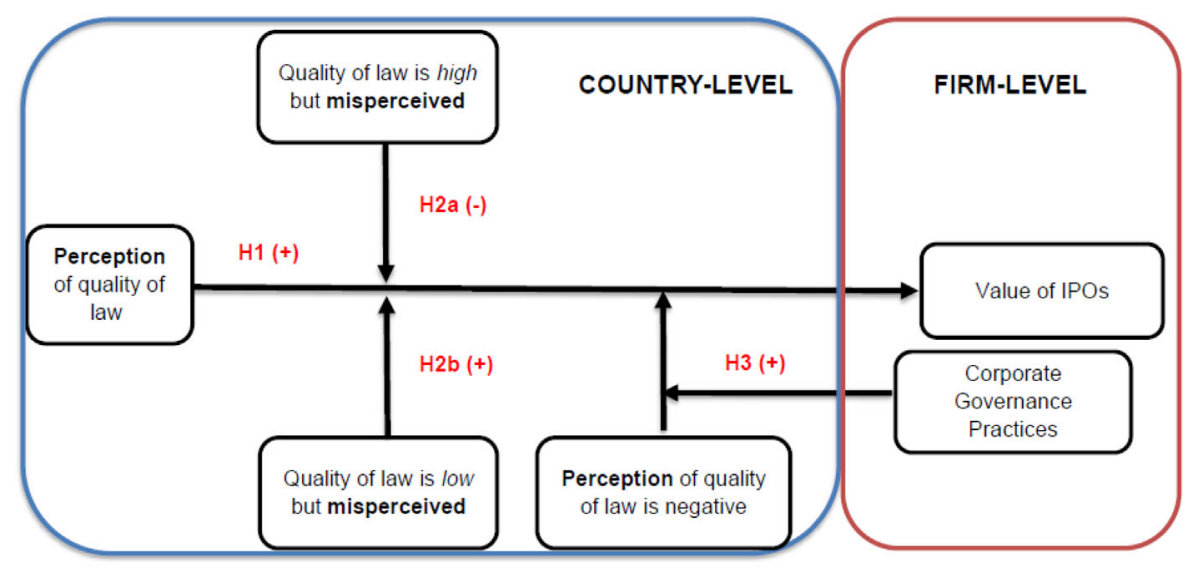

Figure 1. Research model and hypotheses [Colour figure can be viewed at wileyonlinelibrary.com]

governance mechanisms may have less impact on their value. ${ }^{1}$ In such environments, firms can be more selective in adopting corporate governance mechanisms, without a negative impact on their valuation (e.g. Filatotchev, Jona and Livne, 2020). The market may even punish firms that adopt too many corporate governance practices for 'overgoverning' (Aguilera et al., 2008; Bell, Filatotchev and Aguilera, 2014). The impact of firm-level signals on IPO value can therefore be expected to be more indeterminate in positively perceived countries than in negatively perceived ones, and we would therefore expect a differential impact of firm-level corporate governance practices depending on the perception of the country's legal shareholder protection. We hypothesize:

H3: Firm-level corporate governance practices will affect the impact of the perception of country-level law on the value of IPOs, such that the impact will be different for IPOs in countries where the law is negatively perceived than where it is positively perceived.

In short, all of the hypotheses address the underdeveloped role of legal perception in IPOs, be it on its own $(\mathrm{H} 1)$ or in combination with the actual quality of the law $(\mathrm{H} 2 \mathrm{a}$ and $\mathrm{H} 2 \mathrm{~b})$ and with firm-level corporate governance (H3). Figure 1

\footnotetext{
${ }^{1}$ We define 'positive and negative perception' of a given legal environment as the assessment of a given group of actors of the quality of that legal environment compared to a given reference point. An intuitive way of conceiving of negative (positive) perception of a legal system would be that its quality is perceived as below (above) the sample
}

illustrates these hypotheses and their relationship to the country and the firm level. ${ }^{2}$

\section{Data and methods}

\section{Sample description}

We focus on the value of IPOs over the period 2011-2017. Our dataset is taken from five different sources: World Economic Forum, World Bank, Thomson One, Orbis and Refinitiv Eikon. The World Economic Forum (WEF Executive Opinion Surveys) database supplies us with the perception of the quality of legal protection of minority shareholders' interests, with respondents asked to evaluate this aspect of their country's business environment on a scale of 1 (i.e. interests of minority shareholders are not protected by law and seldom recognized by majority shareholders) to 7 (i.e. interests of minority shareholders are protected by law and actively enforced) (World Economic Forum, 2018). These data were collected by the World Economic Forum from 2007 to 2017 from 'business executives from companies of various sizes and from the various sectors of activity' in 140 countries.

average. Yet, there is also a possibility of threshold effects above which a country's legal system may be considered 'good enough' to warrant investment and below which investment is considered risky. Which reference point is appropriate may depend on the precise empirical setting (see further discussion in the Methodology section).

${ }^{2}$ The positive sign for $\mathrm{H} 3$ denotes the existence of a significant effect for countries with negatively perceived law, which we expect to be different for countries with positively perceived law. 
The World Bank (Ease of Doing Business) database provides us with the quality of positive law, namely the 'strength of minority investor protection index', scaled 0 to 100 (best) for 212 countries. The Doing Business Reports' index on minority investor protection has not been without its critics (Deakin, Sarkar and Siems, 2018); yet, it has remained the most widely accepted, globally available dataset on shareholder protection law. Both legal and perception indicators are countrylevel, while the remaining sources provide us with firm-level indicators.

We search for all the IPOs globally from the Thomson One database. We match the firm-level data on the IPOs' pricing and offering to their firm-level financial, accounting and corporate governance data from the Orbis database (Bureau van Dijk) by the firm's unique ISIN (International Securities Identification Number). Corporate governance indicators included board size, board composition, board roles, controlling owners' characteristics and their ownership stakes (Moore and Petrin, 2017). Orbis defines ultimate controlling ownership as the minimum percentage of control in the path from a subject company to its ultimate owner of at least $50.01 \%$. We complement controlling ownership data with ownership data from Refinitiv Eikon database for specific investor types: venture capital (defined as firms providing money to startup firms and small businesses with exceptional growth potential) and private equity funds (defined as providing equity financing to small and middle-market companies). As we merge different data sources, the resulting panel dataset is composed of 2,741 firms that have undergone an IPO in any given year of the 2011-2017 period, of which $40 \%$ are foreign IPOs.

We use two dependent variables for our analysis of firm value. The first one is market return, measured as the first day's closing share price of an issuer's stock divided by the offer price, minus one (Akyol et al., 2014; Judge et al., 2015). The second one is measured by Tobin's Q (ratio of the market value of assets to their book value), as per prior literature (Cremers, Lauterbach and Pajuste, 2018). This measure is longitudinal. The main explanatory variables for our analysis are (1) the country-level perception of the quality of legal protection of minority shareholders' interests and (2) the actual quality of positive law related to the protection of minority shareholders' interests. Both measures are country-level and longitudinal.
A set of corporate governance variables moderate the relation between country-level perception of legal shareholder protection and firm value. We compute board size, which is defined as the natural logarithm of the number of directors and managers for whom the type of role description contains either 'Board of Directors' or 'Senior Management'. The independent directors' ratio is computed as a percentage of independent directors relative to board size. The number of women directors is computed as a natural logarithm of the number of directors for whom gender is indicated as 'Female'. The number of founder-managers is a natural logarithm of the number of directors whose title description contains either 'Founder', 'Shareholder' or 'Owner'. VC/PE ownership is computed as a dummy variable indicating 1 when a firm is owned by either a VC or a PE firm, and 0 otherwise. Committees is a variable that equal 1 when a firm has set up at least one board committee, and 0 otherwise. All measures of corporate governance, except for VC or PE ownership, are cross-sectional.

Finally, we match our set of controls for IPO returns to those defined in the recent literature using cross-country datasets of IPO firms (Akyol et al., 2014; Judge et al., 2015) and Tobin's Q to those defined in Cremers, Lauterbach and Pajuste (2018), as indicated in Table 1. Furthermore, we control for country-level characteristics, such as inflation and GDP growth.

Detailed definitions of these variables are given in Table 1. Descriptive statistics are given in Table 2, followed by information on the countries represented in our dataset in Table 3 and a correlation table of the variables in Table 5.

Table 3 shows that about $20 \%$ are companies established under Chinese law, while the remainder of the most represented countries belong to a variety of developed and emerging economies from different parts of the world. Given a large number of Chinese companies, we have also conducted the subsequent analysis without these firms as a robustness check, with our results being largely unchanged. Table 3 shows that, in our dataset, there are 54 home countries where the IPO firms are incorporated and 64 countries where these firms list. For the purposes of our analysis, the home country is the decisive country for the applicable company law; yet, in the subsequent analysis, we also conducted a robustness check distinguishing between domestic and 


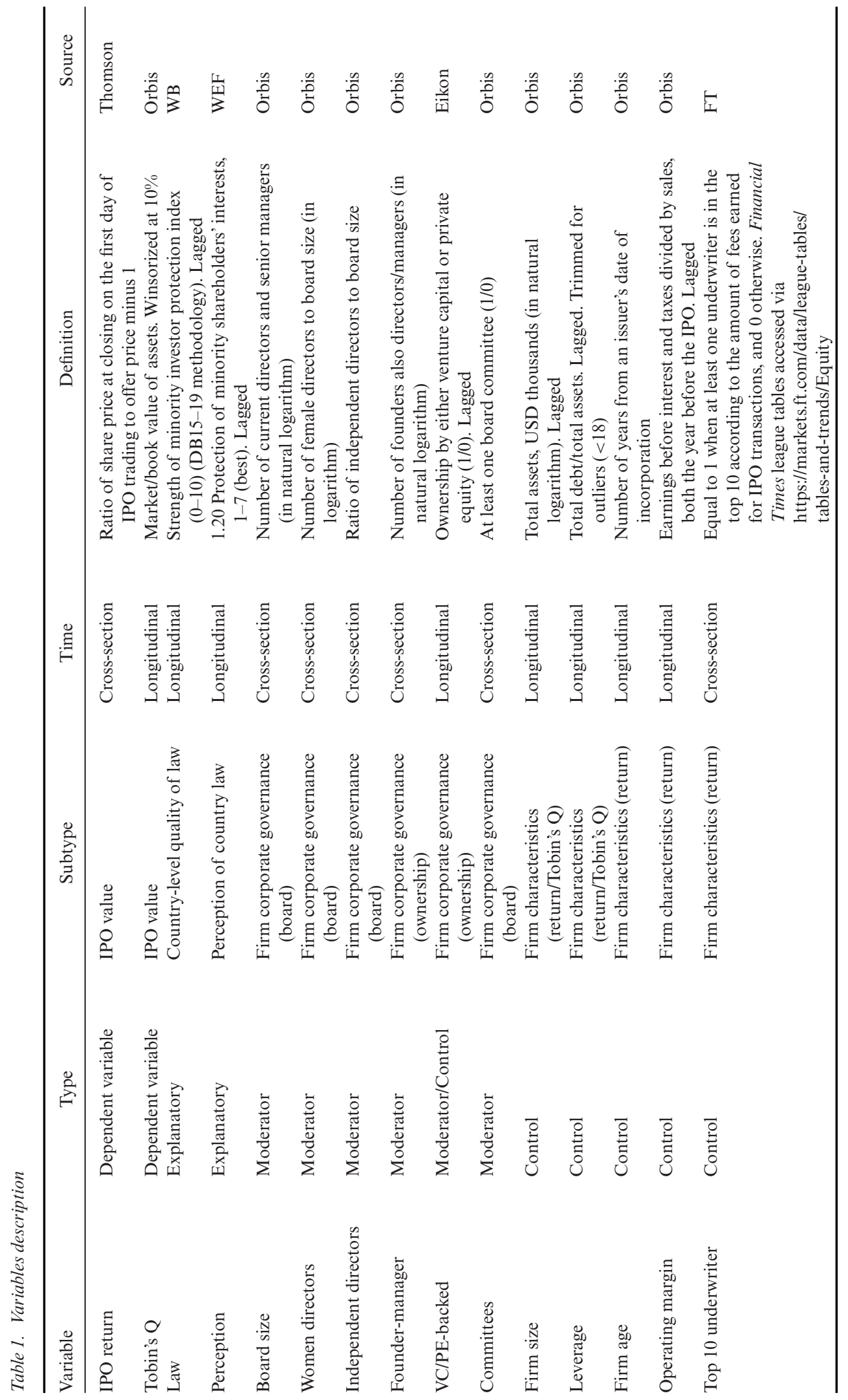




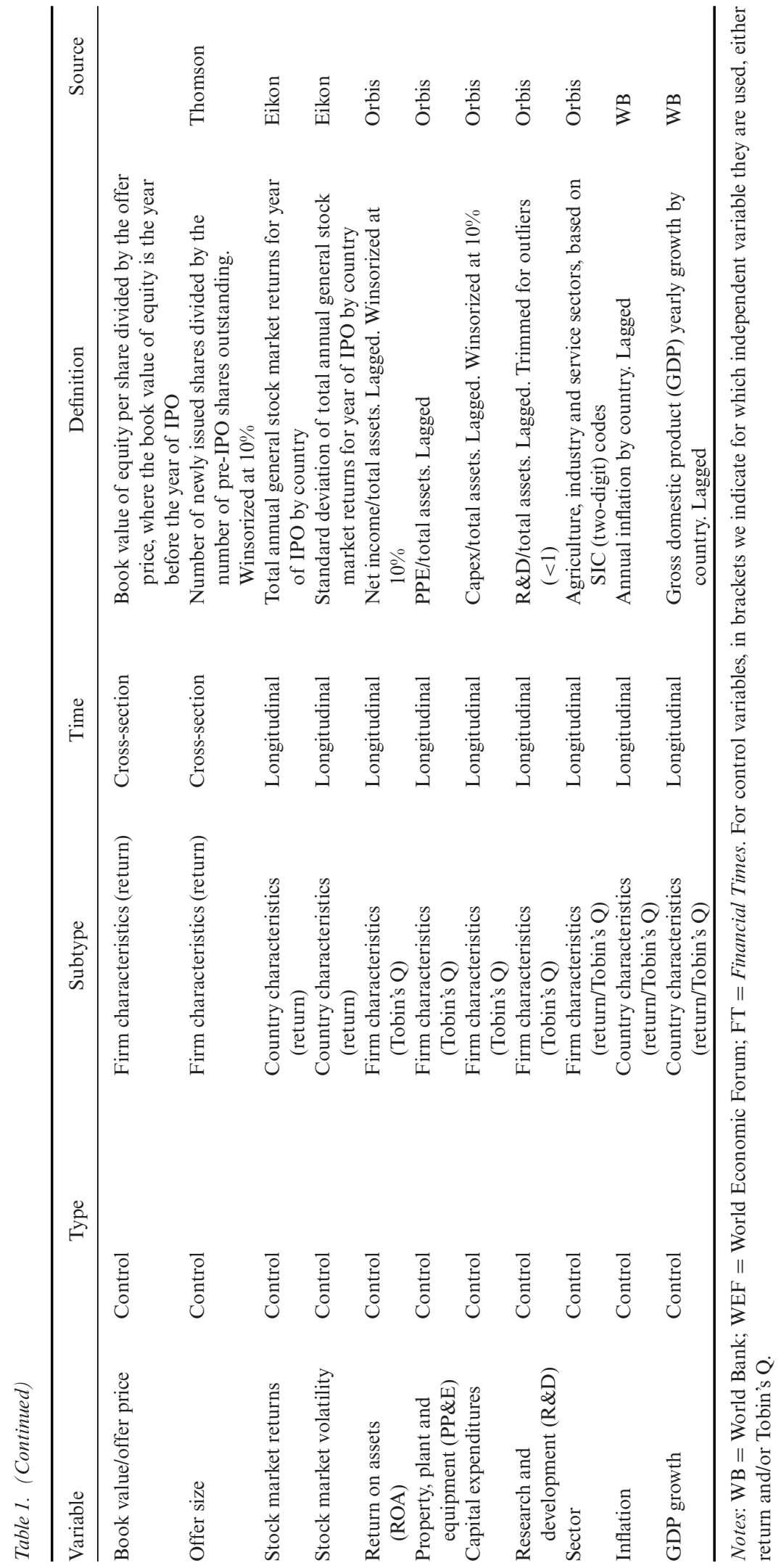


Table 2. Descriptive statistics

\begin{tabular}{|c|c|c|c|c|c|}
\hline Variable & Observations & Mean & Std dev. & Min & $\operatorname{Max}$ \\
\hline \multicolumn{6}{|c|}{ Panel A: Sample of IPO returns (5,126 observations) } \\
\hline \multicolumn{6}{|c|}{ Dependent variables } \\
\hline IPO return (1 day) & 5,156 & -0.73 & 0.44 & -1.00 & 2.21 \\
\hline \multicolumn{6}{|l|}{ Explanatory variables } \\
\hline Law & 5,156 & 63.41 & 12.40 & 30.00 & 96.67 \\
\hline Perception & 5,156 & 4.56 & 0.61 & 3.25 & 6.21 \\
\hline \multicolumn{6}{|l|}{ Control variables } \\
\hline Firm age (years) & 5,156 & 13.83 & 12.39 & 0.00 & 100.00 \\
\hline Operating margin & 5,156 & 0.19 & 1.50 & 0.00 & 105.05 \\
\hline VC/PE-backed & 5,156 & 0.27 & 0.44 & 0.00 & 1.00 \\
\hline Top 10 underwriter & 5,156 & 0.15 & 0.35 & 0.00 & 1.00 \\
\hline Book value/offer price & 5,156 & 0.48 & 0.77 & -0.60 & 28.26 \\
\hline Offer size & 5,156 & 0.25 & 0.21 & 0.02 & 0.75 \\
\hline Stock market returns & 5,156 & 0.34 & 1.51 & -3.41 & 4.47 \\
\hline Stock market volatility & 5,156 & 5.29 & 2.00 & 1.09 & 12.19 \\
\hline Firm size & 5,156 & 11.85 & 1.91 & 0.69 & 18.95 \\
\hline Leverage & 5,156 & 0.00 & 0.32 & -1.00 & 1.56 \\
\hline \multicolumn{6}{|l|}{ Sector } \\
\hline Industry & 5,156 & 0.55 & 0.50 & 0.00 & 1.00 \\
\hline Service & 5,156 & 0.44 & 0.50 & 0.00 & 1.00 \\
\hline Inflation & 5,156 & 2.69 & 2.31 & -1.38 & 13.19 \\
\hline GDP growth & 5,156 & 5.18 & 3.05 & -3.55 & 25.16 \\
\hline \multicolumn{6}{|l|}{ Corporate governance moderators } \\
\hline Founder-manager & 5,156 & -6.18 & 2.17 & -6.91 & 1.61 \\
\hline Board size & 5,156 & 0.98 & 0.76 & 0.00 & 2.94 \\
\hline Female directors & 5,156 & 0.13 & 0.27 & 0.00 & 3.00 \\
\hline Independent directors & 5,156 & 0.40 & 0.38 & 0.00 & 1.00 \\
\hline Committees & 5,156 & 0.26 & 0.44 & 0.00 & 1.00 \\
\hline \multicolumn{6}{|c|}{ Panel B: Sample of Tobin's Q $(15,219$ observations $)$} \\
\hline \multicolumn{6}{|c|}{ Dependent variables } \\
\hline Tobin’s Q & 15,219 & 1.33 & 1.20 & 0.00 & 4.00 \\
\hline \multicolumn{6}{|l|}{ Explanatory variables } \\
\hline Law & 15,219 & 65.07 & 12.50 & 30.00 & 96.67 \\
\hline Perception & 15,219 & 4.66 & 0.61 & 3.03 & 6.22 \\
\hline \multicolumn{6}{|l|}{ Control variables } \\
\hline ROA & 15,219 & 0.02 & 0.09 & -0.18 & 0.13 \\
\hline Firm size & 15,219 & 11.71 & 2.15 & 0.00 & 19.12 \\
\hline Leverage & 15,219 & 0.03 & 0.48 & -1.00 & 17.07 \\
\hline $\mathrm{R} \& \mathrm{D}$ & 15,219 & 0.02 & 0.08 & 0.00 & 0.99 \\
\hline Property, plant and equipment & 15,219 & 0.45 & 0.27 & 0.00 & 1.00 \\
\hline Capital expenditures & 15,219 & 0.01 & 0.00 & 0.00 & 0.01 \\
\hline \multicolumn{6}{|l|}{ Sector } \\
\hline Industry & 15,219 & 0.50 & 0.50 & 0.00 & 1.00 \\
\hline Service & 15,219 & 0.49 & 0.50 & 0.00 & 1.00 \\
\hline Inflation & 15,219 & 2.79 & 2.66 & -1.60 & 20.78 \\
\hline GDP growth & 15,219 & 4.34 & 2.93 & -9.13 & 25.16 \\
\hline \multicolumn{6}{|l|}{ Corporate governance moderators } \\
\hline Founder-manager & 15,219 & -5.90 & 2.51 & -6.91 & 2.08 \\
\hline Board size & 15,219 & 1.03 & 0.75 & 0.00 & 2.94 \\
\hline Female directors & 15,219 & 0.14 & 0.28 & 0.00 & 3.00 \\
\hline Independent directors & 15,219 & 0.37 & 0.37 & 0.00 & 1.00 \\
\hline Committees & 15,219 & 0.21 & 0.41 & 0.00 & 1.00 \\
\hline
\end{tabular}

Notes: For each variable, descriptive statistics are computed on the sample of the specification where this variable is used using the $e$ (sample) command in Stata. For instance, the sample for the specification with IPO return (measured as a ratio of share price at closing on the first day of IPO trading to offer price minus 1) as dependent variable contains 5,156 observations and hence descriptive statistics for all the variables used in this empirical specification are computed on this sample. Conversely, the sample using Tobin's $Q$ (measured yearly, as a ratio of market value to book value of assets) as dependent variable contains 15,219 observations and descriptive statistics for all the variables used in this empirical specification are computed on this sample. 
Table 3. Home, host countries and their distribution

\begin{tabular}{|c|c|c|c|c|c|}
\hline Home country & $\begin{array}{l}\text { Number of } \\
\text { observations }\end{array}$ & $\%$ & Host country & $\begin{array}{l}\text { Number of } \\
\text { observations }\end{array}$ & $\%$ \\
\hline China & 3,096 & 20.34 & China & 2,995 & 19.68 \\
\hline European Union & 2,160 & 14.36 & European Union & 2,164 & 14.22 \\
\hline United Kingdom & 583 & 3.83 & United Kingdom & 609 & 4 \\
\hline Poland & 326 & 2.14 & France & 333 & 2.19 \\
\hline France & 314 & 2.06 & Poland & 290 & 1.91 \\
\hline Sweden & 280 & 1.84 & Sweden & 262 & 1.72 \\
\hline Germany & 148 & 0.97 & Italy & 141 & 0.93 \\
\hline Italy & 144 & 0.95 & Germany & 140 & 0.92 \\
\hline Finland & 73 & 0.48 & Finland & 73 & 0.48 \\
\hline Spain & 69 & 0.45 & Spain & 63 & 0.41 \\
\hline Denmark & 54 & 0.35 & Netherlands & 50 & 0.33 \\
\hline Netherlands & 47 & 0.31 & Denmark & 47 & 0.31 \\
\hline Belgium & 32 & 0.21 & Ireland & 34 & 0.22 \\
\hline Ireland & 29 & 0.19 & Belgium & 30 & 0.2 \\
\hline Luxembourg & 26 & 0.17 & Greece & 22 & 0.14 \\
\hline Greece & 22 & 0.14 & Luxembourg & 19 & 0.12 \\
\hline Bulgaria & 18 & 0.12 & Bulgaria & 18 & 0.12 \\
\hline Malta & 12 & 0.08 & Cyprus & 15 & 0.1 \\
\hline Cyprus & 10 & 0.07 & Malta & 12 & 0.08 \\
\hline United States & 1,532 & 10.07 & Estonia & 6 & 0.04 \\
\hline India & 1,385 & 9.1 & United States & 1,628 & 10.7 \\
\hline South Korea & 1,122 & 7.37 & India & 1,367 & 8.98 \\
\hline Japan & 1,069 & 7.02 & South Korea & 1,127 & 7.41 \\
\hline Australia & 680 & 4.47 & Japan & 1,039 & 6.83 \\
\hline Hong Kong & 662 & 4.35 & Australia & 693 & 4.55 \\
\hline Malaysia & 596 & 3.92 & Hong Kong & 674 & 4.43 \\
\hline Thailand & 555 & 3.65 & Malaysia & 572 & 3.76 \\
\hline Singapore & 487 & 3.2 & Thailand & 545 & 3.58 \\
\hline Indonesia & 261 & 1.71 & Singapore & 504 & 3.31 \\
\hline Canada & 229 & 1.5 & Indonesia & 222 & 1.46 \\
\hline Philippines & 154 & 1.01 & Canada & 220 & 1.45 \\
\hline Saudi Arabia & 141 & 0.93 & Philippines & 151 & 0.99 \\
\hline Turkey & 133 & 0.87 & Saudi Arabia & 134 & 0.88 \\
\hline Brazil & 108 & 0.71 & Turkey & 126 & 0.83 \\
\hline South Africa & 85 & 0.56 & Brazil & 102 & 0.67 \\
\hline Norway & 76 & 0.5 & Brazil & 102 & 0.67 \\
\hline Egypt & 67 & 0.44 & South Africa & 92 & 0.6 \\
\hline Jordan & 61 & 0.4 & Israel & 79 & 0.52 \\
\hline Jordan & 61 & 0.4 & Norway & 75 & 0.49 \\
\hline Israel & 60 & 0.39 & British Virgin & 70 & 0.46 \\
\hline Switzerland & 55 & 0.36 & Switzerland & 69 & 0.45 \\
\hline New Zealand & 53 & 0.35 & Jordan & 61 & 0.4 \\
\hline Sri Lanka & 52 & 0.34 & Egypt & 52 & 0.34 \\
\hline Vietnam & 48 & 0.32 & Vietnam & 48 & 0.32 \\
\hline Mexico & 43 & 0.28 & New Zealand & 46 & 0.3 \\
\hline Bangladesh & 38 & 0.25 & Sri Lanka & 45 & 0.3 \\
\hline Tunisia & 29 & 0.19 & Mexico & 44 & 0.29 \\
\hline Kuwait & 28 & 0.18 & Bangladesh & 33 & 0.22 \\
\hline Pakistan & 27 & 0.18 & Kuwait & 28 & 0.18 \\
\hline Chile & 21 & 0.14 & Pakistan & 25 & 0.16 \\
\hline Russian Fed & 21 & 0.14 & Jersey & 23 & 0.15 \\
\hline Oman & 19 & 0.12 & Tunisia & 23 & 0.15 \\
\hline Kenya & 16 & 0.11 & Chile & 21 & 0.14 \\
\hline Argentina & 12 & 0.08 & Russian Fed & 21 & 0.14 \\
\hline Nigeria & 11 & 0.07 & Taiwan & 18 & 0.12 \\
\hline
\end{tabular}


Table 3. (Continued)

\begin{tabular}{|c|c|c|c|c|c|}
\hline Home country & $\begin{array}{l}\text { Number of } \\
\text { observations }\end{array}$ & $\%$ & Host country & $\begin{array}{l}\text { Number of } \\
\text { observations }\end{array}$ & $\%$ \\
\hline & & & Oman & 14 & 0.09 \\
\hline & & & Cayman Islands & 12 & 0.08 \\
\hline & & & Nigeria & 11 & 0.07 \\
\hline & & & Argentina & 7 & 0.05 \\
\hline & & & Austria & 7 & 0.05 \\
\hline & & & Bahrain & 7 & 0.05 \\
\hline & & & Isle of Man & 7 & 0.05 \\
\hline & & & Macau & 7 & 0.05 \\
\hline & & & Kenya & 5 & 0.03 \\
\hline & & & UAE & 5 & 0.03 \\
\hline & & & Guernsey & 1 & 0.01 \\
\hline Total & 15,219 & 100 & Total & 15,219 & 100 \\
\hline
\end{tabular}

Notes: We have removed the following countries which had fewer than 10 observations from the sample for the analysis: Bahrain, Colombia, Czech Republic, Estonia, Portugal, Hungary, Mongolia, Lithuania, Morocco, Namibia, Peru, Puerto Rico, Qatar, Rwanda and Myanmar. We include an aggregate number of observations for EU countries (as they were in the period examined in this study; thus, it still includes the UK), given the EU's common market despite remaining differences in company law.

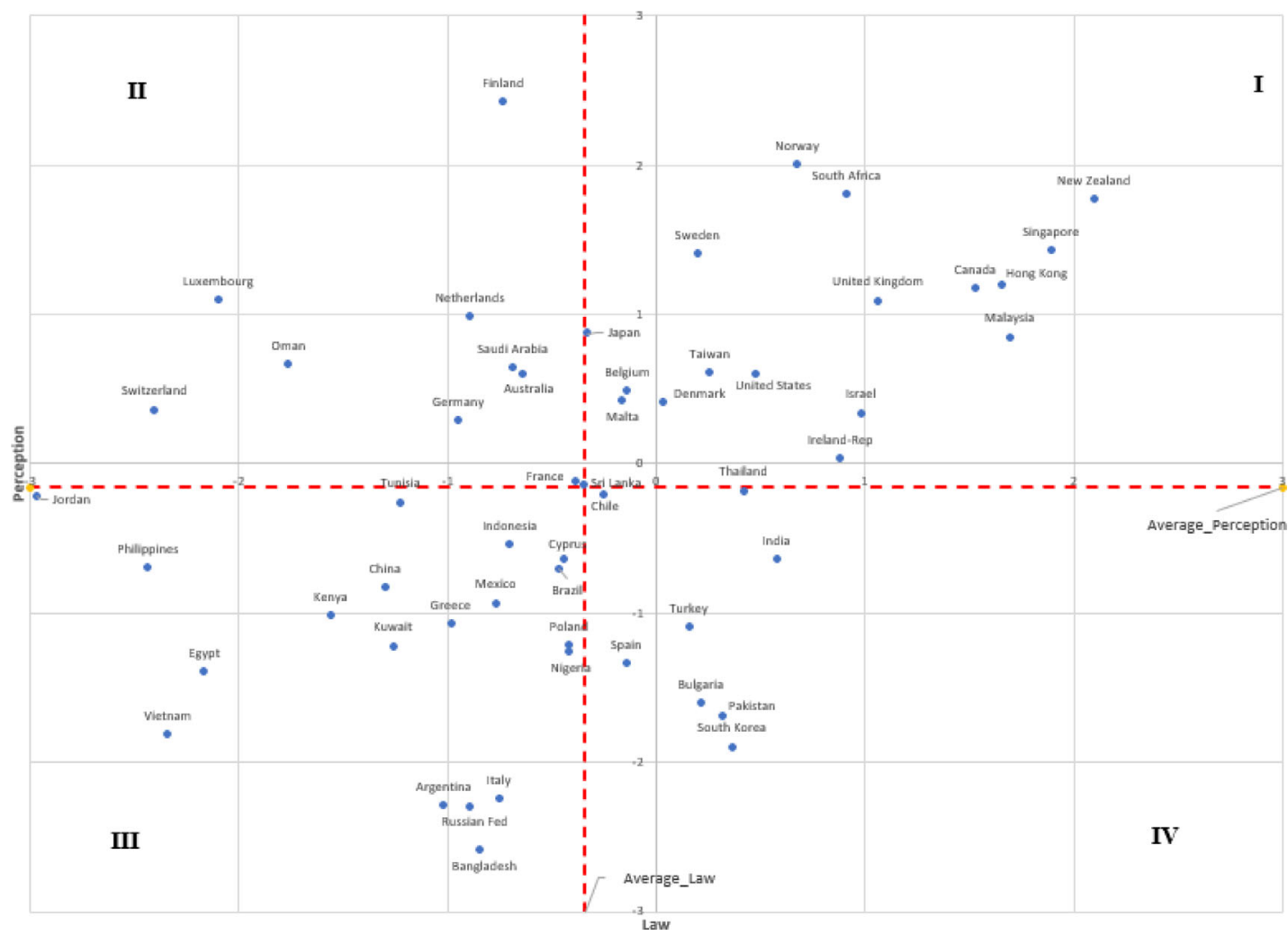

Figure 2. Relationship between law and perception across countries [Colour figure can be viewed at wileyonlinelibrary.com]

foreign IPOs, here too with our results being largely unchanged.

The analysis of this paper hinges on a difference between the positive law on shareholder protection and its perception. Figure 2 displays a scatterplot of the average values of law and its perception for the 54 countries of origin in our dataset. It illustrates that many countries are indeed 'misperceived' according to the two measures we use for actual legal quality and its perception. Indeed, the 
Table 4. Perception of law in 66 home countries where IPO firms are domiciled

\begin{tabular}{|c|c|c|c|}
\hline $\begin{array}{l}\text { Correctly perceived } \\
\text { low-quality law (III) }\end{array}$ & $\begin{array}{l}\text { Correctly perceived } \\
\text { high-quality law (I) }\end{array}$ & $\begin{array}{l}\text { Misperceived } \\
\text { low-quality law (II) }\end{array}$ & $\begin{array}{l}\text { Misperceived } \\
\text { high-quality law (IV) }\end{array}$ \\
\hline Argentina* & Belgium & Australia & Bulgaria* \\
\hline Bangladesh* & Canada & Finland & Chile* \\
\hline Brazil* & Denmark & France & India* \\
\hline China* & Hong Kong & Germany & Pakistan* \\
\hline Cyprus & Ireland-Rep & Luxembourg & South Korea \\
\hline Egypt* & Israel & Netherlands & Spain \\
\hline Greece & Japan & Oman* & Thailand* \\
\hline Indonesia* & Malaysia* & Saudi Arabia* & Turkey* \\
\hline Italy & Malta & Sri Lanka* & \\
\hline Jordan* & New Zealand & Switzerland & \\
\hline Kenya* & Norway & & \\
\hline Kuwait* & Singapore & & \\
\hline Mexico* & South Africa* & & \\
\hline Nigeria* & Sweden & & \\
\hline Philippines* & Taiwan & & \\
\hline Poland* & United Kingdom & & \\
\hline Russian Fed* & United States & & \\
\hline \multicolumn{4}{|l|}{ Tunisia* } \\
\hline \multicolumn{4}{|l|}{ Vietnam* } \\
\hline $35.2 \%$ (19 of the 54 & $31.5 \%$ (17 of the 54 & $18.5 \%$ ( 10 of the 54 & $14.8 \%$ ( 8 of the 54 \\
\hline home countries) & home countries) & home countries) & home countries) \\
\hline
\end{tabular}

* Denotes emerging economies. The roman numerals in brackets refer to quadrants in Figure 2.

'standard view' would lead us to expect the two dimensions to coincide (i.e. country's actual law and its perception are aligned). In Figure 2, this would mean countries would be placed on the $45^{\circ}$ line. If we defined misperception broadly as above average actual law being perceived as below average and vice versa, all countries in quadrants II and IV are misperceived. But even within quadrants we find clusters of misperception: for instance, the group of countries at the bottom of quadrant III - Argentina, Italy, Russia and Bangladesh have considerably worse perception than the near average actual law scores for these countries would seem to justify. This demonstrates that there is considerable variation in our two measures and therefore discrepancies between positive law and its perception are common in the area of legal shareholder protection.

Table 4 further explains how the law in each country is perceived. There are slightly more cases where a low-quality law is correctly perceived (35.2\% of the sample, or 19 of the 54 home countries, with 16 countries being emerging economies); followed by countries where high-quality law is correctly perceived $(31.5 \%$, or 17 of the 54 home countries); then countries with misperceived lowquality law (18.5\%, or 10 of the 54 home countries) and countries with misperceived high-quality law ( $14.8 \%$, or 8 of the 54 home countries).

\section{Methodology}

Our dependent variable is measured by either market returns from the first day of trading of the IPO firm, Returns $s_{i}$, or by the ratio of market to book value, TobinQ $Q_{i t}$, jointly denoted in equations below as $\mathrm{DV}_{\mathrm{i} / \mathrm{it}}$. We use the pooled ordinary least squares (OLS) method where standard errors are computed by clustering at the country level to control for country heterogeneity. ${ }^{3}$ Our empirical specification for $\mathrm{H} 1$, where we test for the direct effect of the perception of law, is defined as follows:

$\mathrm{DV}_{\mathrm{i} / \mathrm{it}}=\alpha+\beta_{1} \mathrm{Law}_{\mathrm{t}}+\beta_{2}$ Perception $_{\mathrm{t}}+\beta_{3} \mathrm{X}_{\mathrm{it}}+\varepsilon_{\mathrm{it}}$

where $\mathrm{Law}_{\mathrm{t}}$ is the legal shareholder protection in a given country at time $t$, Perception ${ }_{t}$ is the perception of this legal shareholder protection in a given country at time $\mathrm{t}$, vector $\mathrm{X}_{\mathrm{it}}$ includes all the appropriate firm-level controls and $\varepsilon_{i t}$ is the error term.

\footnotetext{
${ }^{3}$ The results remain robust to alternative specification using random effects generalized least squares regression with robust standard errors.
} 


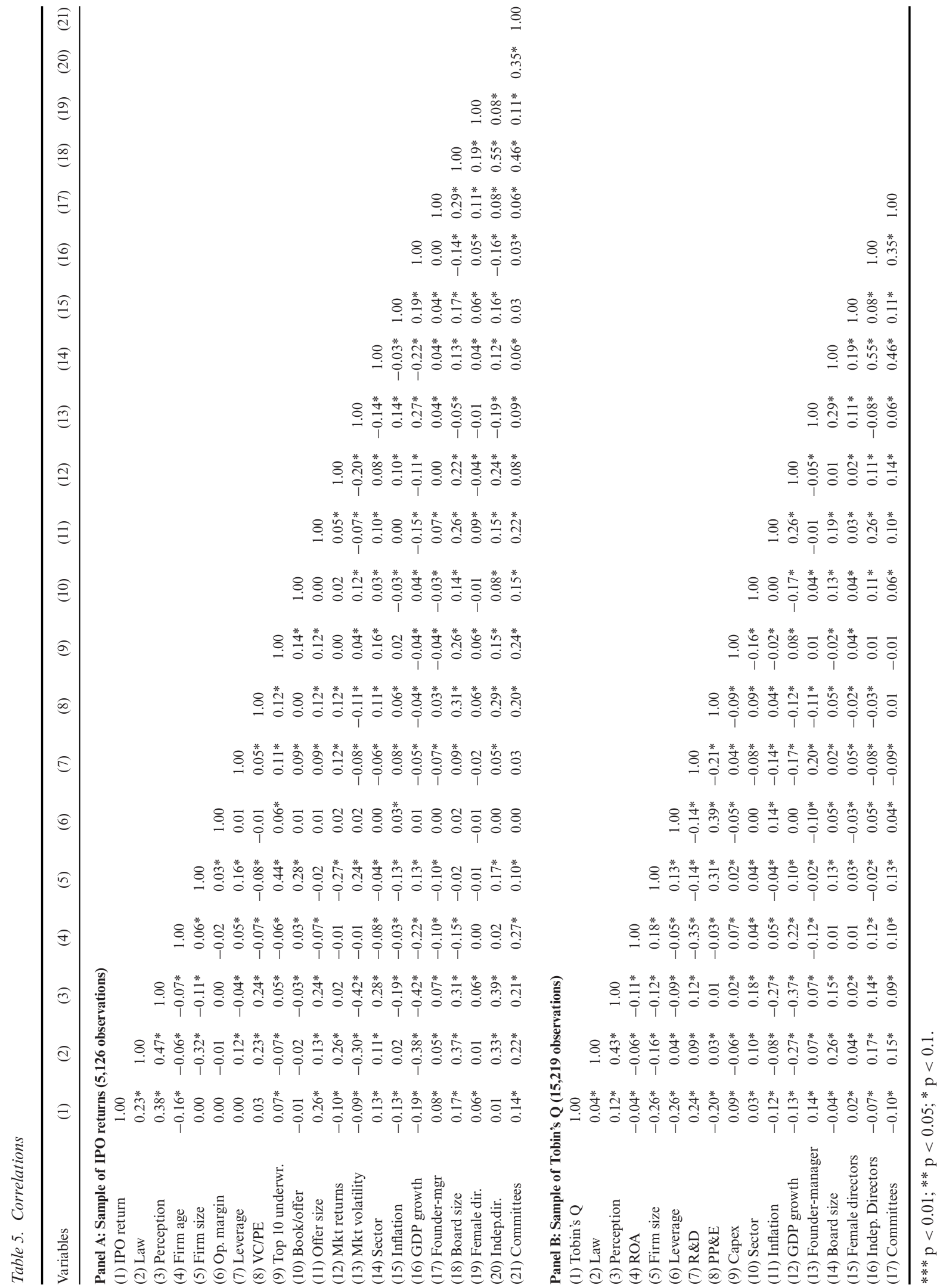


For $\mathrm{H} 2 \mathrm{a}$ and $\mathrm{H} 2 \mathrm{~b}$, where we compare the effect of perception where it is misaligned with the positive law relative to where it is in line with the positive law, our empirical specification is as follows:

$$
\begin{aligned}
\mathrm{DV}_{\mathrm{i}}= & \alpha+\beta_{1} \text { Law }_{\mathrm{t}}+\beta_{2}\left[\text { Perception }_{\mathrm{t}} *\left(\mathrm{~L}_{\mathrm{h}} \mathrm{P}_{1}\right)\right] \\
& +\beta_{3}\left[\text { Perception }_{\mathrm{t}} *\left(\mathrm{~L}_{\mathrm{l}} \mathrm{P}_{\mathrm{h}}\right)\right] \\
& +\beta_{4}\left[\text { Perception }_{\mathrm{t}} *\left(\mathrm{~L}_{\mathrm{h}} \mathrm{P}_{\mathrm{h}}\right)\right] \\
& +\beta_{5}\left[\text { Perception }_{\mathrm{t}} *\left(\mathrm{~L}_{\mathrm{l}} \mathrm{P}_{1}\right)\right]+\beta_{6} \mathrm{X}_{\mathrm{it}}+\varepsilon_{\text {it }}
\end{aligned}
$$

We create four mutually exclusive binary variables of perception and law combinations as per Grosman and Leiponen's (2018) methodology, which we then interact with our continuous measure of perception, Perception $\mathrm{t}_{\mathrm{t}} \mathrm{L}_{\mathrm{h}} \mathrm{P}_{1}$ takes value 1 when the law is high, perception is low, and 0 otherwise (misperception); $\mathrm{L}_{\mathrm{l}} \mathrm{P}_{\mathrm{h}}$ takes value 1 when the law is low, perception is high, and 0 otherwise (misperception); $\mathrm{L}_{\mathrm{h}} \mathrm{P}_{\mathrm{h}}$ takes value 1 when the law is high, perception is high, and 0 otherwise (correctly perceived: law and perception are aligned positively); and $\mathrm{L}_{1} \mathrm{P}_{1}$ takes value 1 when the law is low, perception is low, and 0 otherwise (correctly perceived: law and perception are aligned negatively). This leads to four interactions.

In H3, we test the moderating effect of firm-level corporate governance practices in two subsamples, where we divide the full sample into two groups depending on whether their country law is perceived positively (e.g. perception above average) or negatively (e.g. perception below average). Our empirical specification for each subsample is as follows:

$$
\begin{aligned}
\mathrm{DV}_{\mathrm{i} / \mathrm{it}}= & \alpha+\beta_{1} \text { Law }_{\mathrm{t}}+\beta_{2} \text { Perception }_{\mathrm{t}} \\
& +\beta_{3}\left[\text { Perception }_{\mathrm{t}} * \mathrm{CG}_{\mathrm{i}}\right]+\beta_{4} \mathrm{X}_{\mathrm{it}}+\varepsilon_{\mathrm{it}}
\end{aligned}
$$

where we interact the perception of law with each corporate governance indicator $\mathrm{CG}_{\mathrm{i}}$ (board size, independent directors' ratio, number of women directors, number of founder-managers, board committees or VC/PE ownership). In all specifications, we lag by one period the longitudinal variables to avoid simultaneity bias.

\section{Results}

We first tested our basic claim based on the legal signalling view that perception of law impacts IPO valuation. We estimated this main effect for two different measures of firm valuation: 1-day returns on offer day and Tobin's Q - as a measure of long-term valuation. Results for 1-day returns are reported in Table 6 . They support our first hypothesis, showing that legal perception has a significant (at the 0.05 level) positive effect on 1-day returns (model 1). The effect remains significant (at the 0.05 level) when controlling for total annual stock market returns by country in the year of IPO (model 2). Conversely, the impact of positive law on returns is positive, but non-significant in all models.

We conducted further (untabulated) tests of H1 on subsamples of domestic and foreign IPOs, where our results for the overall sample were confirmed: perception was positive and significant for the IPO returns for both domestic IPOs and foreign IPOs. We have also conducted tests on a subsample of advanced markets, where H1 was strongly supported.

Using Tobin's Q as an alternative DV (Table 7) lends further support to H1. Legal perception has a positive and significant effect (at the 0.05 level) on IPO valuation measured as Tobin's Q (model 1). Controlling for GDP growth, the results remain positive and significant (at the 0.1 level, model 2). The impact of actual legal shareholder protection has - contrary to the standard view - a negative sign, although it is only significant for model 2 (at the 0.1 level).

Taken together, these results provide strong support for $\mathrm{H} 1$ and therefore for the basic insight of the legal signalling view that what drives IPO valuation is not so much the actual quality of legal shareholder protection (positive law) in a country, but rather the perception of its law.

To test $\mathrm{H} 2 \mathrm{a}$ and $\mathrm{H} 2 \mathrm{~b}$, we further investigated the role of legal perception by focusing on the issue of correct perception versus misperception of law. We created four mutually exclusive dummy variables to capture each combination of the strength of actual legal shareholder protection and its perception (strong law, negative misperception; strong law, correct positive perception; weak law, positive misperception; weak law, correct negative perception), which we interacted with the continuous measure of perception.

Table 8 reports the findings for IPO returns on the first day of trading. We first note that the main effect of the impact of positive law on IPO value is insignificant, suggesting that law per se does not impact valuation. 
Table 6. The effects of law perception on IPO returns (H1)

\begin{tabular}{|c|c|c|}
\hline \multirow[b]{2}{*}{ Independent variables } & Model 1 & Model 2 \\
\hline & Dependent variable: 1 -day return & Dependent variable: 1 -day return \\
\hline \multirow{2}{*}{ Law, lagged } & 0.108 & 0.130 \\
\hline & $(0.141)$ & $(0.144)$ \\
\hline \multirow[t]{2}{*}{ Perception, lagged } & $0.307 * *$ & $0.283^{* *}$ \\
\hline & $(0.130)$ & $(0.128)$ \\
\hline \multirow[t]{2}{*}{ Firm age } & $-0.123^{*}$ & $-0.124^{*}$ \\
\hline & $(0.069)$ & $(0.068)$ \\
\hline \multirow[t]{2}{*}{ Firm size, lagged } & 0.025 & -0.006 \\
\hline & $(0.072)$ & $(0.069)$ \\
\hline \multirow[t]{2}{*}{ Operating margin, lagged } & -0.001 & 0.002 \\
\hline & $(0.007)$ & $(0.007)$ \\
\hline \multirow[t]{2}{*}{ Leverage, lagged } & -0.000 & 0.010 \\
\hline & $(0.037)$ & $(0.038)$ \\
\hline \multirow[t]{2}{*}{ VCPE-backed, lagged } & $-0.091 * *$ & $-0.082 *$ \\
\hline & $(0.044)$ & $(0.043)$ \\
\hline \multirow[t]{2}{*}{ Top 10 underwriter } & 0.031 & 0.042 \\
\hline & $(0.039)$ & $(0.038)$ \\
\hline \multirow[t]{2}{*}{ Book value/offer price } & -0.018 & -0.008 \\
\hline & $(0.021)$ & $(0.017)$ \\
\hline \multirow[t]{2}{*}{ Offer size } & 0.167 & $0.169^{*}$ \\
\hline & $(0.100)$ & $(0.099)$ \\
\hline \multirow[t]{2}{*}{ Stock market volatility } & 0.081 & 0.063 \\
\hline & $(0.059)$ & $(0.061)$ \\
\hline \multirow[t]{2}{*}{ Stock market returns } & & $-0.121 *$ \\
\hline & & $(0.061)$ \\
\hline \multirow[t]{2}{*}{ Industry sector } & -0.166 & -0.149 \\
\hline & $(0.224)$ & $(0.239)$ \\
\hline \multirow[t]{2}{*}{ Service sector } & -0.109 & -0.080 \\
\hline & $(0.227)$ & $(0.246)$ \\
\hline \multirow[t]{2}{*}{ Inflation, lagged } & -0.111 & -0.104 \\
\hline & $(0.068)$ & $(0.066)$ \\
\hline \multirow[t]{2}{*}{ GDP growth, lagged } & -0.011 & -0.014 \\
\hline & $(0.134)$ & $(0.129)$ \\
\hline \multirow[t]{2}{*}{ Constant } & -0.016 & -0.046 \\
\hline & $(0.322)$ & $(0.334)$ \\
\hline Year dummies & Yes & Yes \\
\hline Observations & 5,156 & 5,156 \\
\hline R-squared & 0.220 & 0.231 \\
\hline
\end{tabular}

Notes: In this table, we report results from pooled OLS regressions that we use to examine the effects of Perception of home country legal shareholder protection on IPO stock returns from the first day of trading. Heteroscedasticity robust standard errors in parentheses, clustered by country. All dynamic variables are lagged by one period to address endogeneity concerns related to simultaneity bias. All variables are standardized using the z-score formula for comparability of coefficients. We winsorized observations of $\mathrm{O} f f e r$ size by replacing all values lower than the $10 \%$ percentile and higher than the $90 \%$ percentile with the respective values of the two boundaries. Each regression controls for time effects (2012-2017) and industry effects.

$* * * \mathrm{p}<0.01 ; * * \mathrm{p}<0.05 ; * \mathrm{p}<0.10$.

Comparing the coefficients for the case of strong legal shareholder protection, first we find that the coefficient for misperception (law high, perception low) is non-significant in all four models. However, for perception correctly assessing the quality of positive law (law high, perception high), we find a positive and significant effect at the 0.05 level (model 1). Controlling for total annual stock market returns by country during the IPO year, the significance remains at the 0.05 level (model 2). In other words, in the case of strong legal shareholder protection, the effect of legal perception on IPO valuation is stronger if the perception is aligned with positive law than when the quality of law is misperceived. This is consistent with $\mathrm{H} 2 \mathrm{a}$ and confirms that the perception of law plays an important 
Table 7. The effects of law perception on value of IPOs (H1)

\begin{tabular}{|c|c|c|}
\hline & Model 1 & $>$ Model 2 \\
\hline Independent variables & Dependent variable: Tobin's Q & Dependent variable: Tobin's Q \\
\hline Law, lagged & $\begin{array}{c}-0.041 \\
(0.029)\end{array}$ & $\begin{array}{r}-0.047 * \\
(0.028)\end{array}$ \\
\hline Perception, lagged & $\begin{array}{l}0.061^{* *} \\
(0.027)\end{array}$ & $\begin{array}{c}0.050^{*} \\
(0.029)\end{array}$ \\
\hline ROA, lagged & $\begin{array}{c}0.083^{*} \\
(0.041)\end{array}$ & $\begin{array}{l}0.088^{* *} \\
(0.040)\end{array}$ \\
\hline Firm size, lagged & $\begin{array}{l}-0.230^{* * *} \\
(0.036)\end{array}$ & $\begin{array}{c}-0.225^{* * *} \\
(0.034)\end{array}$ \\
\hline Leverage, lagged & $\begin{array}{l}-0.166^{* * *} \\
(0.060)\end{array}$ & $\begin{array}{c}-0.166^{* * *} \\
(0.060)\end{array}$ \\
\hline R\&D, lagged & $\begin{array}{l}0.186^{* * *} \\
(0.025)\end{array}$ & $\begin{array}{l}0.181^{* * *} \\
(0.025)\end{array}$ \\
\hline Property, plant and equipment, lagged & $\begin{array}{c}-0.025 \\
(0.044)\end{array}$ & $\begin{array}{c}-0.032 \\
(0.044)\end{array}$ \\
\hline Capital expenditures, lagged & $\begin{array}{l}0.083^{* * *} \\
(0.016)\end{array}$ & $\begin{array}{l}0.085^{* * *} \\
(0.016)\end{array}$ \\
\hline Industry sector & $\begin{array}{c}0.148 \\
(0.174)\end{array}$ & $\begin{array}{c}0.143 \\
(0.176)\end{array}$ \\
\hline Service sector & $\begin{array}{c}0.211 \\
(0.152)\end{array}$ & $\begin{array}{c}0.197 \\
(0.155)\end{array}$ \\
\hline Inflation, lagged & $\begin{array}{l}-0.101^{* * *} \\
(0.031)\end{array}$ & $\begin{array}{c}-0.089 * * * \\
(0.028)\end{array}$ \\
\hline GDP growth, lagged & & $\begin{array}{c}-0.056^{*} \\
(0.030)\end{array}$ \\
\hline Year dummies & Yes & Yes \\
\hline Constant & $\begin{array}{c}-0.407^{*} \\
(0.211)\end{array}$ & $\begin{array}{r}-0.348 \\
(0.216)\end{array}$ \\
\hline Observations & 15,219 & 15,219 \\
\hline R-squared & 0.182 & 0.184 \\
\hline
\end{tabular}

Notes: In this table, we report results from pooled OLS regressions that we use to examine the effects of Perception of home country legal shareholder protection on IPO's firm Tobin's $Q$. Heteroscedasticity robust standard errors in parentheses, clustered by country. All dynamic variables are lagged by one period to address endogeneity concerns related to simultaneity bias. All variables are standardized using the z-score formula for comparability of coefficients. We winsorized observations of Tobin's Q, ROA and Capital expenditures by replacing all values lower than the $10 \%$ percentile and higher than the $90 \%$ percentile with the respective values of the two boundaries. Leverage and $R \& D$ variables are trimmed for excessive values $(<18$ and $<1$, respectively). Each regression controls for time effects (2012-2017) and industry effects. We have removed countries with only a small number of observations $(<10)$ : Bahrain, Botswana, Colombia, Czech Republic, Estonia, Portugal, Hungary, Mongolia, Lithuania, Morocco, Namibia, Peru, Puerto Rico, Qatar, Rwanda and Myanmar.

$* * * \mathrm{p}<0.01 ; * * \mathrm{p}<0.05 ; * \mathrm{p}<0.10$.

role, independently of the actual quality of the law.

Comparing the coefficients of the weak legal shareholder protection cases, we find that when weak legal shareholder protection is correctly perceived as weak, the effect of perception on IPO value is non-significant. Conversely, when weak legal shareholder protection is misperceived as strong, the impact on returns is positive and significant (at the 0.05 level), confirming $\mathrm{H} 2 \mathrm{~b}$ which posited that the positive relationship between le- gal perception and IPO value is enhanced if low shareholder protection law is incorrectly positively perceived.

These findings are confirmed when using Tobin's $\mathrm{Q}$ as an alternative DV (Table 9). In model 2, the positive perception cases show a significant and positive coefficient, independently of whether the actual law offers high levels of shareholder protection or not. Conversely, when the law is - correctly or incorrectly - negatively perceived, the effect is non-significant. 
Table 8. The effects of perception on IPO returns when the law is misperceived ( $\mathrm{H} 2 \mathrm{a}$ and $\mathrm{H} 2 \mathrm{~b}$ )

\begin{tabular}{|c|c|c|}
\hline \multirow[b]{2}{*}{ Independent variables } & Model 1 & Model 2 \\
\hline & DV: 1-day return & DV: 1-day return \\
\hline \multirow[t]{2}{*}{ Law, lagged } & 0.181 & 0.192 \\
\hline & $(0.214)$ & $(0.213)$ \\
\hline \multirow{2}{*}{$\begin{array}{l}\text { Perception } \times \text { (law high, perception low), } \\
\text { lagged }\end{array}$} & 0.687 & 0.631 \\
\hline & $(0.503)$ & $(0.494)$ \\
\hline \multirow{2}{*}{$\begin{array}{l}\text { Perception } \times \text { (law low, perception high) } \\
\text { lagged }\end{array}$} & $0.264 * *$ & $0.252 * *$ \\
\hline & $(0.121)$ & $(0.121)$ \\
\hline \multirow{2}{*}{$\begin{array}{l}\text { Perception } \times \text { (law high, perception high), } \\
\text { lagged }\end{array}$} & $1.003^{*}$ & $0.923^{*}$ \\
\hline & $(0.531)$ & $(0.525)$ \\
\hline \multirow{2}{*}{$\begin{array}{l}\text { Perception } \times \text { (law low, perception low), } \\
\text { lagged }\end{array}$} & 0.849 & 0.771 \\
\hline & $(0.545)$ & $(0.530)$ \\
\hline \multirow[t]{2}{*}{ Firm age } & $-0.110^{*}$ & $-0.113^{*}$ \\
\hline & $(0.063)$ & $(0.062)$ \\
\hline \multirow[t]{2}{*}{ Firm size, lagged } & 0.005 & -0.022 \\
\hline & $(0.063)$ & $(0.063)$ \\
\hline \multirow[t]{2}{*}{ Operating margin, lagged } & 0.001 & 0.003 \\
\hline & $(0.006)$ & $(0.007)$ \\
\hline \multirow[t]{2}{*}{ Leverage, lagged } & 0.003 & 0.012 \\
\hline & $(0.034)$ & $(0.035)$ \\
\hline \multirow[t]{2}{*}{ VCPE-backed, lagged } & $-0.089 * *$ & $-0.080^{*}$ \\
\hline & $(0.043)$ & $(0.042)$ \\
\hline \multirow[t]{2}{*}{ Top 10 underwriter } & 0.032 & 0.042 \\
\hline & $(0.038)$ & $(0.037)$ \\
\hline \multirow[t]{2}{*}{ Book value/offer price } & -0.016 & -0.006 \\
\hline & $(0.019)$ & $(0.016)$ \\
\hline \multirow[t]{2}{*}{ Offer size } & 0.165 & $0.167^{*}$ \\
\hline & $(0.100)$ & $(0.099)$ \\
\hline \multirow[t]{2}{*}{ Stock market volatility } & 0.079 & 0.062 \\
\hline & $(0.058)$ & $(0.060)$ \\
\hline \multirow[t]{2}{*}{ Stock market returns } & & $-0.116^{* *}$ \\
\hline & & $(0.056)$ \\
\hline \multirow[t]{2}{*}{ Industry sector } & -0.199 & -0.181 \\
\hline & $(0.212)$ & $(0.220)$ \\
\hline \multirow[t]{2}{*}{ Service sector } & -0.133 & -0.105 \\
\hline & $(0.198)$ & $(0.214)$ \\
\hline \multirow[t]{2}{*}{ Inflation, lagged } & -0.079 & -0.076 \\
\hline & $(0.079)$ & $(0.079)$ \\
\hline \multirow[t]{2}{*}{ GDP growth, lagged } & -0.045 & -0.039 \\
\hline & $(0.143)$ & $(0.139)$ \\
\hline Year dummies & Yes & Yes \\
\hline \multirow[t]{2}{*}{ Constant } & 0.049 & 0.012 \\
\hline & $(0.324)$ & $(0.329)$ \\
\hline Observations & 5,156 & 5,156 \\
\hline R-squared & 0.237 & 0.248 \\
\hline
\end{tabular}

Notes: Heteroscedasticity robust standard errors in parentheses, clustered by country. The type of level of Law and Perception is determined by their mean (e.g. High above the mean and Low below the mean, such that the variable (Law High, Perception Low) takes value 1 if the law is above the mean AND perception is below the mean, and 0 otherwise). All variables are standardized using the z-score formula for comparability of coefficients. All dynamic variables are lagged by one period to address endogeneity concerns related to simultaneity bias. We winsorized observations of Offer size by replacing all values lower than the $10 \%$ percentile and higher than the $90 \%$ percentile with the respective values of the two boundaries. Each regression controls for time effects (2012-2017) and industry effects.

$* * * \mathrm{p}<0.01 ; * * \mathrm{p}<0.05 ; * \mathrm{p}<0.10$. 
Table 9. The effects of perception on value of IPOs when the law is misperceived ( $\mathrm{H} 2 \mathrm{a}$ and $\mathrm{H} 2 \mathrm{~b}$ )

\begin{tabular}{|c|c|c|}
\hline & Model 1 & Model 2 \\
\hline Independent variables & Dependent variable: Tobin's Q & Dependent variable: Tobin's Q \\
\hline Law, lagged & $\begin{array}{c}-0.023 \\
(0.029)\end{array}$ & $\begin{array}{c}-0.051 \\
(0.038)\end{array}$ \\
\hline $\begin{array}{l}\text { Perception } \times \text { (law high, perception low), } \\
\text { lagged }\end{array}$ & & $\begin{array}{l}0.025 \\
(0.028)\end{array}$ \\
\hline $\begin{array}{l}\text { Perception } \times \text { (law low, perception high), } \\
\quad \text { lagged }\end{array}$ & & $\begin{array}{l}0.107^{* * *} \\
(0.011)\end{array}$ \\
\hline $\begin{array}{l}\text { Perception } \times \text { (law high, perception high), } \\
\quad \text { lagged }\end{array}$ & & $\begin{array}{l}0.126^{* * *} \\
(0.042)\end{array}$ \\
\hline $\begin{array}{l}\text { Perception } \times \text { (law low, perception low), } \\
\text { lagged }\end{array}$ & & $\begin{array}{c}0.068 \\
(0.042)\end{array}$ \\
\hline ROA, lagged & $\begin{array}{r}0.066^{*} \\
(0.038)\end{array}$ & $\begin{array}{l}0.084^{* *} \\
(0.036)\end{array}$ \\
\hline Firm size, lagged & $\begin{array}{c}-0.228^{* * *} \\
(0.035)\end{array}$ & $\begin{array}{c}-0.237 * * * \\
(0.036)\end{array}$ \\
\hline Leverage, lagged & $\begin{array}{l}-0.184 * * * \\
(0.064)\end{array}$ & $\begin{array}{l}-0.179 * * * \\
(0.064)\end{array}$ \\
\hline R\&D, lagged & $\begin{array}{l}0.194 * * * \\
(0.024)\end{array}$ & $\begin{array}{l}0.196 * * * \\
(0.028)\end{array}$ \\
\hline Property, plant and equipment, lagged & $\begin{array}{c}-0.007 \\
(0.044)\end{array}$ & $\begin{array}{c}-0.014 \\
(0.045)\end{array}$ \\
\hline Capital expenditures, lagged & $\begin{array}{l}0.078^{* * *} \\
(0.016)\end{array}$ & $\begin{array}{l}0.080^{* * *} \\
(0.014)\end{array}$ \\
\hline Industry sector & $\begin{array}{c}0.121 \\
(0.175)\end{array}$ & $\begin{array}{c}0.137 \\
(0.178)\end{array}$ \\
\hline Service sector & $\begin{array}{c}0.239 \\
(0.150)\end{array}$ & $\begin{array}{c}0.203 \\
(0.157)\end{array}$ \\
\hline Inflation, lagged & $\begin{array}{l}-0.091 * * \\
(0.036)\end{array}$ & $\begin{array}{l}-0.083 * * * \\
(0.030)\end{array}$ \\
\hline Year dummies & Yes & Yes \\
\hline Constant & $\begin{array}{c}-0.431^{* *} \\
(0.194)\end{array}$ & $\begin{array}{c}-0.432^{* *} \\
(0.212)\end{array}$ \\
\hline Observations & 17,061 & 17,061 \\
\hline R-squared & 0.179 & 0.187 \\
\hline
\end{tabular}

Notes: Heteroscedasticity robust standard errors in parentheses, clustered by country. All variables are standardized using the z-score formula for comparability of coefficients. All dynamic variables are lagged by one period to address endogeneity concerns related to simultaneity bias. We winsorized observations of Tobin's $Q, R O A$ and Capital expenditures by replacing all values lower than the $10 \%$ percentile and higher than the $90 \%$ percentile with the respective values of the two boundaries. Leverage and $R \& D$ variables are trimmed for excessive values ( $<18$ and $<1$, respectively). Each regression controls for time effects (2012-2017) and industry effects. We have removed countries with only a small number of observations $(<10)$ : Bahrain, Botswana, Colombia, Czech Republic, Estonia, Portugal, Hungary, Mongolia, Lithuania, Morocco, Namibia, Peru, Puerto Rico, Qatar, Rwanda and Myanmar.

$* * * \mathrm{p}<0.01 ; * * \mathrm{p}<0.05 ; * \mathrm{p}<0.10$.

Taken together, these findings lend strong support to $\mathrm{H} 2 \mathrm{a}$ and $\mathrm{H} 2 \mathrm{~b}$, in the sense that highquality law that is misperceived does not impact valuation, while misperceived low-quality law has a positive effect. These findings corroborate the view that the signalling effect dominates the efficiency effect of law and that perception is quite independent of the actual quality of the law.

To test H3, we collected data on a series of important firm-level corporate governance practices considered in the literature to impact firm performance including valuation (Bhagat, Bolton and Romano, 2008). In particular, we included 
important corporate governance mechanisms regarding ownership (involvement of founder in firm management; the presence of venture capitalist or private equity firm amongst owners), board size, board composition (percentage of independent directors), board diversity (number of female directors) and board structure (presence of committees). For each one of these variables, we split our sample into two subsamples based on whether the company is based in a country with negative (below average) legal perception or positive (above average) legal perception.

Table 10 presents the results for testing $\mathrm{H} 3$ based on these variables. ${ }^{4}$ The results provide strong evidence in support of $\mathrm{H} 3$, which hypothesized that the impact of firm-level corporate governance on the relationships between perception and IPO value differs depending on legal perception. The total effect of perception on IPO returns for firms with each corporate governance mechanism (as measured by the sum of the coefficients on perception and on the interaction between perception and a corporate governance mechanism) is consistently significant and negative for the negative perception subsample (each reported Wald test for joint significance of coefficients is significant at the 0.1 or 0.05 levels) and positive but insignificant for the positive perception subsample. The only exception of this consistent pattern is founder involvement in management, which is negative and significant for both subsamples.

In other words, in negatively perceived countries, higher levels of firm-level corporate governance reduce the positive impact of legal perception on firms' IPO value. In positively perceived countries, firm-level corporate governance mechanisms do not affect the relationship between perception and valuation.

Figures A1-A6 in the Appendix further illustrate these moderating effects for each corporate governance indicator. Taking Figure $\mathrm{A} 1$ as an example, we evaluate the impact of law perception on the valuation of IPO firms at two different levels of founder-managers (one standard deviation above and below the mean of the founder-

\footnotetext{
${ }^{4}$ In the interest of space, we only report results for one DV, namely IPO returns. We carried out robustness checks with the alternative DV, Tobin's Q. Results are available upon request. We have also run similar tests for additional corporate governance mechanisms, which are available upon request.
}

managers variable). The slopes for the quadrant with negative perception are of opposite coefficient, confirming the negative moderating effect of founder-managers in the relationship between law perception and firms' IPO return. As we can see from the quadrant with negative perception, when the number of founder-managers is high, higher legal perception is negatively associated with firms' IPO returns (downward slope); while when the number of founder-managers is low, increases in the law perception would lead to higher IPO returns (upward slope). Given that founder-manager involvement is usually considered a desirable corporate governance feature, this can be interpreted as support for the firm signalling view. The slopes in the quadrant with positive perception are both upward, and the slope of lower numbers of founder-managers is steeper than the slope of higher numbers of founder-managers, which means that there is a negative impact of numbers of founder-managers on the relationship between law perception and IPO returns. Similar explanations apply to the other corporate governance mechanisms we tested (Figures A2-A6). The analysis of the interaction effects reveals that for all our corporate governance practices, firms with higher levels of corporate governance are more highly valued than firms with lower levels of corporate governance the more legal perception is negative. As the legal perception becomes less negative, the positive effect of corporate governance declines and ultimately becomes negative, while the effect of low levels of corporate governance becomes positive as legal perception improves. In sum, these figures provide support for the 'firm signalling view' for the negative perception subsample.

Taken together, these results lend strong support for $\mathrm{H} 3$ by clearly showing that the effect of firmlevel corporate governance mechanisms on the relationship between perception and IPO value is different for the two subsamples.

\section{Robustness checks}

We ran a series of robustness checks for all three hypotheses. Firstly, we followed Katelouzou and Siems' (2015) approach to check for structural breaks in our time-series data by performing a series of yearly Chow tests (results available upon request). We did not detect any structural breaks that would imply that the relationship we observe 


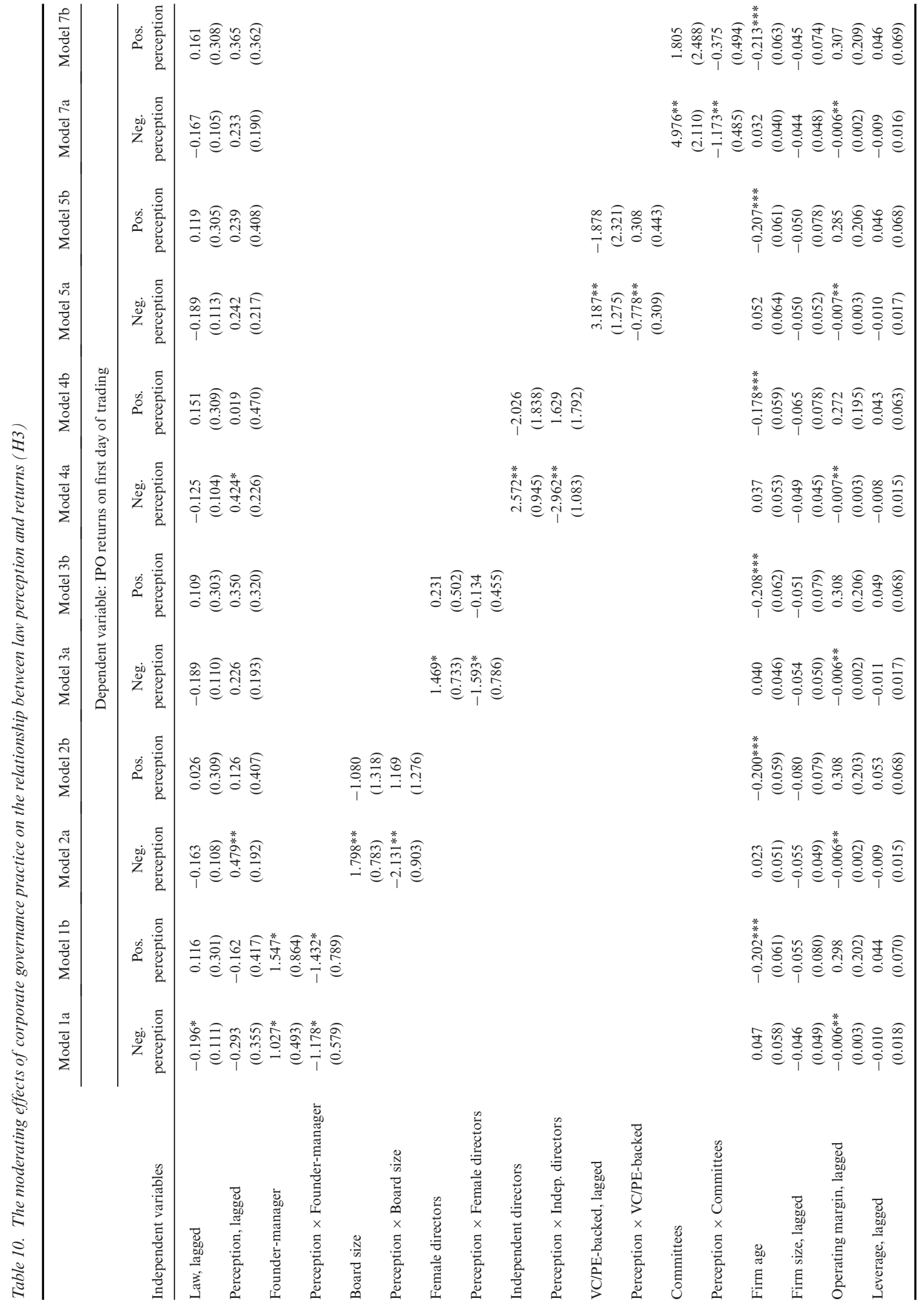




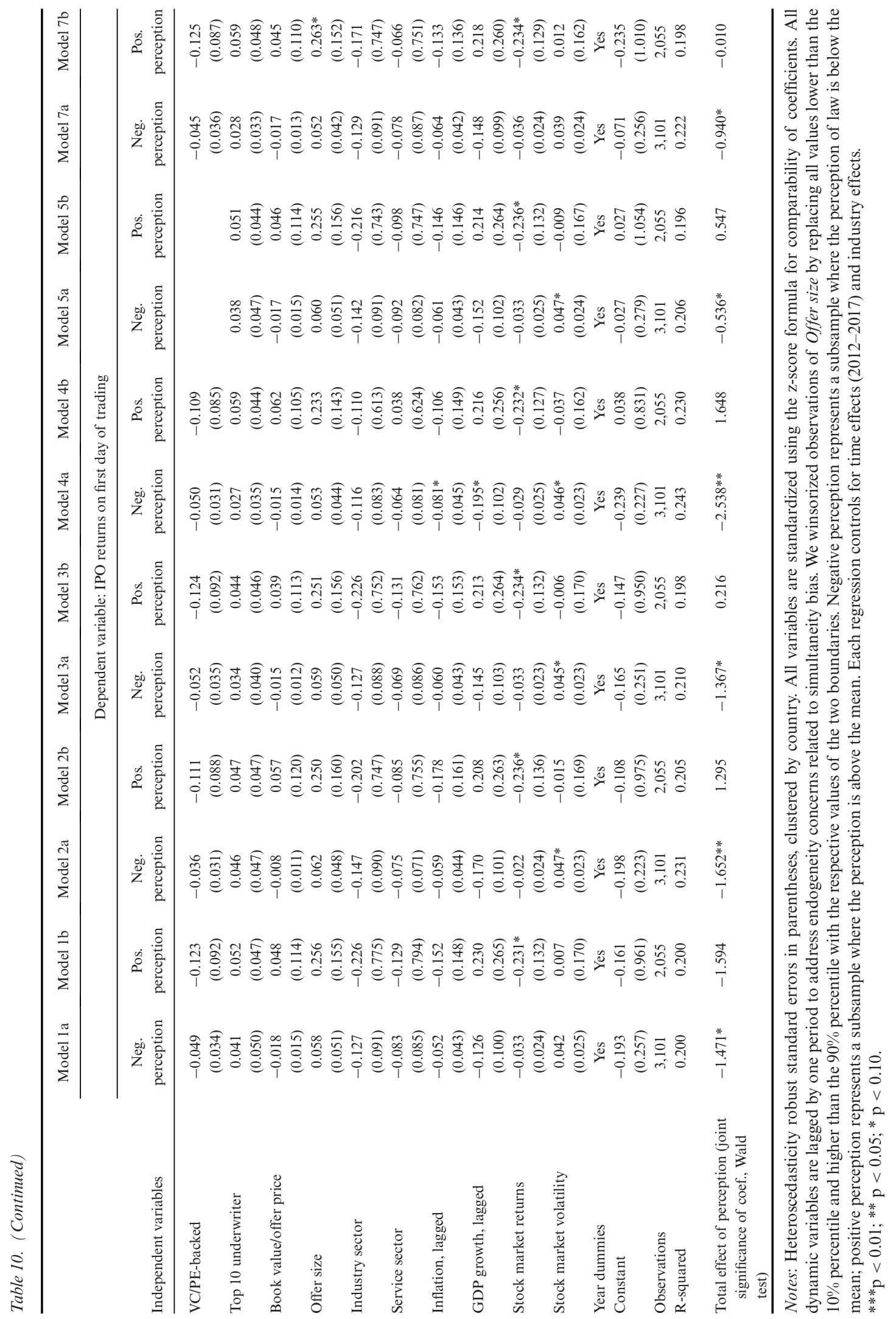


Table 11. The effects of law perception on value of IPOs (system GMM)

System GMM

Independent variables

Dependent variable - Tobin's Q

\begin{tabular}{|c|c|}
\hline Law & $\begin{array}{c}-0.053^{*} \\
(0.029)\end{array}$ \\
\hline Perception & $\begin{array}{l}0.412^{* *} \\
(0.195)\end{array}$ \\
\hline ROA & $\begin{array}{c}1.189^{* *} \\
(0.604)\end{array}$ \\
\hline Firm size & $\begin{array}{c}-0.155^{* * *} \\
(0.035)\end{array}$ \\
\hline Leverage & $\begin{array}{c}-0.341 \text { *** } \\
(0.099)\end{array}$ \\
\hline $\mathrm{R} \& \mathrm{D}$ & $\begin{array}{l}0.975^{* *} \\
(0.253)\end{array}$ \\
\hline PPE & $\begin{array}{c}-0.287 \\
(0.243)\end{array}$ \\
\hline Capex & $\begin{array}{c}30.334 * \\
(17.289)\end{array}$ \\
\hline GDP growth & $\begin{array}{c}-0.069^{* *} \\
(0.030)\end{array}$ \\
\hline Inflation & $\begin{array}{c}0.005 \\
(0.023)\end{array}$ \\
\hline Sector dummies & Yes \\
\hline Time dummies & Yes \\
\hline Observations & 14,981 \\
\hline Number of firms & 3,054 \\
\hline Number of instruments & 23 \\
\hline $\operatorname{AR}(1)$ & -6.632 \\
\hline $\operatorname{AR}(1)$ ( $p$ value) & 0.000 \\
\hline $\operatorname{AR}(2)$ & -1.574 \\
\hline $\operatorname{AR}(2)$ ( $p$ value) & 0.115 \\
\hline $\operatorname{AR}(3)$ & -0.876 \\
\hline $\operatorname{AR}(3)$ ( $p$ value) & 0.381 \\
\hline Sargan test & 198.1 \\
\hline Sargan (p value) & 0.000 \\
\hline Hansen test & 8.576 \\
\hline Hansen ( $p$ value) & 0.036 \\
\hline
\end{tabular}

Difference-in-Hansen tests of exogeneity of instrument subsets:

GMM instruments for levels

Hansen test excluding group: $\chi^{2}(1)=5.40$. Prob $>\chi^{2}=0.020$

Difference (null $\mathrm{H}=$ exogenous): $\chi^{2}(2)=3.18$. Prob $>\chi^{2}=0.204$

GMM (Tobin's Q, collapse eq(diff) $\operatorname{lag}(66))$

Hansen test excluding group: $\chi^{2}(2)=7.77$. Prob $>\chi^{2}=0.021$

Difference (null $\mathrm{H}=$ exogenous): $\chi^{2}(1)=0.81$. Prob $>\chi^{2}=0.370$

GMM (Tobin's Q, collapse eq(level) $\operatorname{lag}(5$ 5))

Hansen test excluding group: $\chi^{2}(2)=6.40$. Prob $>\chi^{2}=0.041$

Difference (null $\mathrm{H}=$ exogenous): $\chi^{2}(1)=2.17$. Prob $>\chi^{2}=0.141$

GMM (law, eq(diff) $\operatorname{lag}(88)$ )

Hansen test excluding group: $\chi^{2}(0)=1.02$. Prob $>\chi^{2}=$.

Difference (null $\mathrm{H}=$ exogenous): $\chi^{2}(3)=7.56$. Prob $>\chi^{2}=0.056$

GMM(law, collapse eq(level) $\operatorname{lag}(6$ 6))

Hansen test excluding group: $\chi^{2}(2)=7.82$. Prob $>\chi^{2}=0.020$

Difference (null $\mathrm{H}=$ exogenous): $\chi^{2}(1)=0.76$. Prob $>\chi^{2}=0.383$

Notes: Heteroscedasticity robust standard errors in parentheses, clustered by country. We use the xtabond2 command developed by Roodman (2009). We use instruments in levels dated t-8 (Law) and t-6 (Tobin's Q) for the equations in first differences and firstdifferenced instruments dated t-5 (Tobin's Q) and t-6 (Law) for the equations in levels. We use the collapse option to limit instrument proliferation. AR(1), AR(2) and AR(3) are tests for the absence of first, second and third-order serial correlations in the residuals, asymptotically distributed as $\mathrm{N}(0,1)$ under the null of no serial correlation. The Sargan test is for the over-identifying restrictions, it is 
not robust to heteroscedasticity and autocorrelation, but it is not weakened by many instruments. Hence, we also report the Hansen $\mathbf{J}$ test, which is robust but weakened by many instruments. We report difference-in-Hansen tests for exogeneity of the subsets of instruments. The number of instruments does not exceed the number of firms. The Hansen's J statistic of instrument exogeneity is low, robust, but may be weakened by many instruments. The Arellano-Bond test statistic indicative of no second or higher-order autocorrelation of residuals $\mathrm{AR}(2)$ is not significant, consistent with the Arellano-Bond approach, and does not provide evidence of misspecification. The difference-in-Hansen tests of exogeneity of instrument subsets show that the selection of instruments is appropriate (we cannot reject the null hypothesis that the instruments are valid).

$* * * \mathrm{p}<0.01 ; * * \mathrm{p}<0.05 ; * \mathrm{p}<0.10$.

between legal perception, positive law and IPO value changes over time.

Secondly, we ran the same specifications as above, including business group affiliation as an additional control variable (not tabulated), to test for the reputational effect of being part of a larger business group. Our results remain substantively unchanged.

Finally, to check for various types of endogeneity concerns (i.e. omitted variable bias, simultaneous and dynamic endogeneity), we ran a series of estimations using Blundell and Bond's (1998) generalized methods of moments (GMM) as a system, following the methodological toolkit produced by Abdallah, Goergen and O'Sullivan (2015). Table 11 reports the results from a GMM estimation testing our first hypothesis using Tobin's Q as the dependent variable. We use Tobin's $Q$ because this variable is dynamic and allows us to use its lags as instruments. The results confirm our findings from the OLS, showing a significant $(0.05$ level) positive effect of legal perception on firm valuation, while actual law is moderately significant ( 0.10 level) but negative. Untabled robustness checks for $\mathrm{H} 2 \mathrm{a}$ and $\mathrm{H} 2 \mathrm{~b}$ using a similar GMM estimation with Tobin's $Q$ largely support our findings as well, except for $\mathrm{H} 2 \mathrm{~b}$.

\section{Discussion and conclusion}

This paper seeks to contribute to the corporate finance and Law and Finance literatures by introducing a new concept that we label 'legal signalling', and which explicitly distinguishes the actual (or positive) law and the perception of law as two distinct concepts. This view constitutes an alternative approach to what we called the 'standard view' of the role of law in finance, which is inspired by classical legal positivism. The 'standard view' assumes that law's role is to reduce transaction costs, increasing certainty and protecting property rights, which can be summarized as law's 'efficiency effect'. We enhance the concept of law in Law and Finance by adding the 'legal signalling' effect, which is based on the insight that the actual law and how law is perceived at the country level may be two different things. Taking into account 'legal perception' at the country level allows us to capture the complexity of the relationship between the positive law, its perception, firm-level corporate governance practices and IPO valuation. Table 12 presents an overview of the eight possible combinations of these three factors: quality of law, perception of law and firm corporate governance practices.

Overall, our results lend strong support to the legal signalling view. Our study is the first to clearly distinguish and empirically test the differences between the efficiency and the signalling effects of law. We show that the perception of the law matters more than the actual quality of the law for the valuation of IPO firms. Our findings challenge prior literature (notably Law and Finance studies), which assumes that 'law matters' but does not consider that the quality of the law and the perception of the quality of the law often diverge.

Our study also contributes to previous studies on perception, by demonstrating the importance of considering the fact that law is often misperceived. We investigate the effect of legal perception, or the general perception of a country's shareholder protection laws as opposed to investor perception of these laws. This insight suggests that studies on the impact of perception on IPO value (Bell, Filatotchev and Aguilera, 2014; Filatotchev, Jona and Livne, 2020), which have relied on investor perception, may benefit from looking at the additional effects of how the law is perceived. Our novel conceptualization includes theorizing the 
Table 12. Three views of law, perception and governance practice interaction

\begin{tabular}{|c|c|c|c|c|c|c|}
\hline \multirow[b]{2}{*}{$\begin{array}{l}\text { Combin- } \\
\text { ations }\end{array}$} & \multicolumn{3}{|c|}{ Possible determinants } & \multicolumn{3}{|c|}{$\begin{array}{l}\text { Expected impact on performance and firm valuation } \\
\text { according to different views }\end{array}$} \\
\hline & $\begin{array}{c}\text { Quality of } \\
\text { positive } \\
\text { law }\end{array}$ & Perception of law & $\begin{array}{c}\text { Firm corporate } \\
\text { governance practices }\end{array}$ & $\begin{array}{l}\text { Standard view (Law } \\
\text { and Finance studies) }\end{array}$ & $\begin{array}{c}\text { Firm signalling } \\
\text { view }\end{array}$ & $\begin{array}{c}\text { Legal signalling } \\
\text { view }\end{array}$ \\
\hline 1 & High & $\begin{array}{l}\text { Positive (correct } \\
\text { perception) }\end{array}$ & $\begin{array}{l}\text { Good (aligned with } \\
\text { law) }\end{array}$ & + & + & + \\
\hline 2 & High & $\begin{array}{l}\text { Negative } \\
\quad \text { (misperception) }\end{array}$ & $\begin{array}{l}\text { Good (aligned with } \\
\text { law) }\end{array}$ & + & + & - \\
\hline 3 & High & $\begin{array}{l}\text { Positive (correct } \\
\text { perception) }\end{array}$ & $\begin{array}{l}\text { Bad (deviating from } \\
\text { law) }\end{array}$ & + & $+I-$ & + \\
\hline 4 & High & $\begin{array}{l}\text { Negative } \\
\quad \text { (misperception) }\end{array}$ & $\begin{array}{l}\text { Bad (deviating from } \\
\text { law) }\end{array}$ & + & $+I-$ & - \\
\hline 5 & Low & $\begin{array}{l}\text { Positive } \\
\text { (misperception) }\end{array}$ & $\begin{array}{l}\text { Good (deviating } \\
\text { from law) }\end{array}$ & - & + & + \\
\hline 6 & Low & $\begin{array}{l}\text { Negative (correct } \\
\text { perception) }\end{array}$ & $\begin{array}{l}\text { Good (deviating } \\
\text { from law) }\end{array}$ & - & + & - \\
\hline 7 & Low & $\begin{array}{l}\text { Positive } \\
\quad \text { (misperception) }\end{array}$ & $\begin{array}{l}\text { Bad (aligned with } \\
\text { law) }\end{array}$ & - & + & + \\
\hline 8 & Low & $\begin{array}{l}\text { Negative (correct } \\
\text { perception) }\end{array}$ & $\begin{array}{l}\text { Bad (aligned with } \\
\text { law) }\end{array}$ & - & - & - \\
\hline
\end{tabular}

Note $:+=$ positive association hypothesized; $-=$ negative association hypothesized $+/-=$ direction of association undetermined.

interactions of perception of law with firm-level corporate governance practices, and evidence of the substitution effects of firm-level governance when the perception of country law is negative.

Our focus has been to test the legal signalling view, which takes the perception of the law into account but also conceives the institutional effects on firm valuation as being the result of the interplay of all three determinants: actual law, its perception and firm-level governance. We hypothesized that perception would dominate positive law $(\mathrm{H} 1)$, which is borne out by our empirical analysis (as illustrated by the column 'Legal signalling view' in Table 12: combinations 1, 3, 5 and 7 with positive perception will lead to positive IPO value, while combinations 2, 4, 6 and 8 with negative perception will lead to negative IPO value, irrespective of the quality of law).

To further distinguish the legal signalling from the efficiency effect of law, we investigated the misperception of law (H2a and H2b). We hypothesized that when investors correctly perceived weak law, the value of an IPO would be more negatively affected (combinations 6 and 8 in Table 12) than when the weak law is misperceived (combinations 5 and 7 in Table 12). Our findings support these hypotheses. Indeed, regardless of the actual quality of law, positive perception (e.g. when perception of the law is above average) will lead to a positive effect of perception on IPO value (combinations 1 , 3, 5 and 7 in Table 12). This lends strong support to the dominance of the legal signalling effect over the efficiency effect of law.

We find support for $\mathrm{H} 3$, predicting that the effect of firm-level corporate governance mechanisms of IPO value will differ between positively and negatively perceived countries. Our findings for $\mathrm{H} 3$ also support the idea that corporate governance practices can compensate for negative legal perception (e.g. when perception of the law is below average) in some cases. Indeed, consistent with previous studies, we uncover that an increase in firm-level corporate governance mechanisms in countries with negatively perceived law positively affects valuation when the levels of perception are low (combinations 2 and 6). For the positive perception subsample (combinations 1 and 5), firm-level corporate governance does not influence the relationship between law and IPO valuation.

For countries with positive legal perception, our results for $\mathrm{H} 3$ can be interpreted as showing that the legal framework may be considered sufficient to guarantee a reasonable level of shareholder protection for investors and any additional firm-level corporate governance mechanism may be seen as 'over-governance' (Aguilera et al., 2008) that constrains managerial leeway and 
imposes additional firm costs. Therefore, firm-level corporate governance does not have a significant impact on the relationship between perception and IPO value for such countries. This hints at the contextual nature of the firm signalling effect, which depends not just on the level of actual legal shareholder protection but also on its perception. Further research is needed to disentangle the precise nature of the perception of firm-level governance and country-level law.

A limitation of our study is that our findings may be influenced by the selection of corporate governance mechanisms we tested. It may often not be clear a priori what type of firm-level corporate governance investors prefer. For example, there is a large literature on many of these governance practices, with conflicting findings of whether independent directors and board diversity have a positive impact on firm valuation (Adams and Ferreira, 2009; Ahern and Dittmar, 2012; Bhagat and Black, 2001; Duchin, Matsusaka, and Ozbas, 2010; Knyazeva, Knyazeva and Masulis, 2013; Moore and Petrin, 2017). Further studies could investigate in more detail how legal signalling and firm-level corporate governance practices interact in order to gain a fuller picture of perception effects and their relationship to the positive law.

To conclude, this study has shown that research on Law and Finance can benefit from further reconceptualization of the role of law. Clearly, it is not just the positive law, but the perception of that law that matters. This supports a more sociological or behavioural view of law and suggests the need for further studies to examine the role of law in the economy. The boundary effects of firm-level corporate governance on country-level perception should also be acknowledged.

Our approach complicates the picture of the institutional determinants of IPO value but also opens new avenues for future research that can draw on the recent insights on subjective perception from fields such as behavioural law and economics.

Our findings also hint at limitations to firms' abilities to signal good practice to investors and market participants. While we find support that such effects exist in countries whose laws are negatively perceived - thus confirming existing studies (Khanna and Palepu, 2004) - the fact that firm signals do not have an effect in cases where the law is positively perceived shows that in some contexts firms have relatively little control over their 'reputation'. Conversely, this finding also suggests that in some circumstances investors seem to be driven by broader contextual factors beyond the firm level - which we call 'legal signals' - underscoring the importance of contextual approaches to studying corporate governance and finance phenomena.

The findings about the relationship between positive law and its perception also have implications for a broad range of fields beyond corporate governance and finance, where economic activity is driven by legal rules. Our approach is an important step towards a better understanding of internationalized and cross-border financial markets, to which Professor Mike Wright's work has made a lasting contribution.

\section{Funding}

This study was funded by the Economic and Social Research Council (Grants No. RES-061-25-0518).

\section{References}

Abdallah, W., M. Goergen and N. O'Sullivan (2015). 'Endogeneity: how failure to correct for it can cause wrong inferences and some remedies', British Journal of Management, 26, pp. 791804.

Adams, R. B. and D. Ferreira (2009). 'Women in the boardroom and their impact on governance and performance', Journal of Financial Economics, 94, pp. 291-309.

Aguilera, R. V. and A. Cuervo-Cazurra (2004). 'Codes of good governance worldwide: what is the trigger?', Organization Studies, 25, pp. 415-443.

Aguilera, R. V. and C. A. Williams (2009). "Law and Finance": inaccurate, incomplete, and important', Brigham Young University Law Review, 1, pp. 1413-1434.

Aguilera, R. V., W. Q. Judge and S. A. Terjesen (2016). 'Corporate governance deviance', Academy of Management Review, 43, pp. $1-49$.

Aguilera, R. V., I. Filatotchev, H. Gospel and G. Jackson (2008). 'An organizational approach to comparative corporate governance: costs, contingencies, and complementarities', Organization Science, 19, pp. 475-492.

Ahern, K. R. and A. K. Dittmar (2012). 'The changing of the boards: the impact on firm valuation of mandated female board representation', The Quarterly Journal of Economics, 127, pp. 137-197.

Akyol, A. C., T. Cooper, M. Meoli and S. Vismara (2014). 'Do regulatory changes affect the underpricing of European IPOs?', Journal of Banking \& Finance, 45, pp. 43-58.

Becker, G. (1968). 'Crime and punishment: an economic approach', Journal of Political Economy, 76, pp. 169-217.

Bell, R. G., I. Filatotchev and R. V. Aguilera (2014). 'Corporate governance and investors' perceptions of foreign IPO value: 
an institutional perspective', Academy of Management Journal, 57, pp. 301-320.

Bhagat, S. and B. Black (2001). 'The non-correlation between board independence and long-term firm performance', Journal of Corporation Law, 27, p. 231-273.

Bhagat, S., B. Bolton and R. Romano (2008). 'The promise and peril of corporate governance indices', Columbia Law Review, 108, pp. 1803-1882.

Bhagat, S., J. Lu and S. Rangan (2019). 'IPO valuation: the international evidence'. In D. Cumming and S. Johan (eds), Oxford Handbook of IPOs, pp. 108-145. Oxford: Oxford University Press.

Blundell, R. and S. Bond (1998). 'Initial conditions and moment restrictions in dynamic panel data models', Journal of Econometrics, 87, pp. 115-143.

Brav, A. and P. A. Gompers (2003). 'The role of lockups in initial public offerings', The Review of Financial Studies, 16, pp. 1-29.

Bromley, P. and W. W. Powell (2012). 'From smoke and mirrors to walking the talk: decoupling in the contemporary world', The Academy of Management Annals, 6, pp. 483-530.

Chahine, S. (2008). 'Underpricing versus gross spread: new evidence on the effect of sold shares at the time of IPOs', Journal of Multinational Financial Management, 18, pp. 180-196.

Chahine, S., M. Goergen and S. Saade (2021). 'Foreign venture capitalists and access to foreign research: the case of US initial public offerings', British Journal of Management, this issue.

Chahine, S., I. Filatotchev, G. D. Bruton and M. Wright (2019). "Success by association": the impact of venture capital firm reputation trend on initial public offering valuations', Journal of Management, 47, pp. 368-398.

Chisholm, D. (1995). 'Problem solving and institutional design', Journal of Public Administration Research and Theory, 5, pp. 451-491.

Coakley, J., L. Hadass and A. Wood (2007). 'Post-IPO operating performance, venture capital and the bubble years', Journal of Business Finance and Accounting, 34, pp. 1423-1446.

Coffee, J. (1999). 'The future as history: the prospects for global convergence in corporate governance and its implications', Northwestern University Law Review, 93, pp. 641-708.

Coffee, J. (2007). 'Law and the market: the impact of enforcement', University of Pennsylvania Law Review, 156, pp. 229311.

Colby, H. and M. Ryznar (2019). 'An empirical study of family law understanding', University of Louisville Law Review, $\mathbf{5 8}$, pp. 79-99.

Cremers, M., B. Lauterbach and A. Pajuste (2018). 'The life-cycle of dual class firm valuation', ECGI Finance Working Paper 550 .

Cumming, D. J. and J. G. MacIntosh (2000). 'The role of interjurisdictional competition in shaping Canadian corporate law', International Review of Law and Economics, 20, pp. 141186.

Cumming, D. J. and J. G. MacIntosh (2002). 'The rationales underlying reincorporation and implications for Canadian corporations', International Review of Law and Economics, 22, pp. 277-330.

Cumming, D., D. Schmidt and U. Walz (2010). 'Legality and venture capital governance around the world', Journal of Business Venturing, 25, pp. 54-72.
Cumming, D., M. Deloof, S. Manigart and M. Wright (2019). 'New directions in entrepreneurial finance', Journal of Banking and Finance, 100, pp. 252-260.

Deakin, S., P. Sarkar and M. Siems (2018). 'Is there a relationship between shareholder protection and stock market development?', Journal of Law, Finance, and Accounting, 3, pp. 115146.

Deakin, S., D. Gindis, G. M. Hodgson, K. Huang and K. Pistor (2017). 'Legal institutionalism: capitalism and the constitutive role of law', Journal of Comparative Economics, 45, pp. 188200.

Derrien, F. and K. L. Womack (2003). Auctions vs. Bookbuilding and the control of underpricing in Hot IPO markets. Review of Financial Studies, 16, pp. 31-61. https://doi.org/10.1093/rfs/ 16.1.31.

DiMaggio, P. J. and W. W. Powell (1983). 'The iron cage revisited: institutional isomorphism and collective rationality in organizational fields', American Sociological Review, 48, pp. 147-160.

Djankov, S., E. Glaeser, L. Porta, F. Lopez-de-Silanes and A. Shleifer (2003). 'The new comparative economics', Journal of Comparative Economics, 31, pp. 595-619.

Duchin, R., J. G. Matsusaka and O. Ozbas (2010). 'When are outside directors effective?', Journal of Financial Economics, 96, pp. 195-214.

Engelen, P. J. and M. van Essen (2010). 'Underpricing of IPOs: firm-, issue- and country-specific characteristics', Journal of Banking \& Finance, 34, pp. 1958-1969.

Estrin, S., T. Mickiewicz, U. Stephan and M. Wright (2019). 'Entrepreneurship in emerging markets'. In R. Gross and K. E. Meyer (eds), The Oxford Handbook of Management in Emerging Markets, p. 457ff. Oxford: Oxford University Press.

Fattoum-Guedri, A., F. Delmar and M. Wright (2018). 'The best of both worlds: can founder-CEOs overcome the rich versus king dilemma after IPO?', Strategic Management Journal, 39, pp. 3382-3407.

Filatotchev, I., J. Jona and G. Livne (2020). 'Earnings management in domestic and foreign IPOs in the United States: do home country institutions matter?', European Accounting Review, 29, pp. 307-335.

Filatotchev, I., M. Wright and G. D Bruton (2017). 'IPOs and corporate governance'. In M. A. Hitt, S. E. Jackson, S. Carmona, L. Bierman, C. E. Shalley and D. M. Wright (eds), The Oxford Handbook of Strategy Implementation, p. 79ff. Oxford: Oxford University Press.

Fini, R., K. Fu, M. T. Mathisen, E. Rasmussen and M. Wright (2017). 'Institutional determinants of university spinoff quantity and quality: a longitudinal, multilevel, crosscountry study', Small Business Economics, 48, pp. 361-391.

Gande, A. and D. P. Miller (2012). 'Why do U.S. securities laws matter to non-U.S. firms? Evidence from private class-action lawsuits', AFA 2013 San Diego Meetings Paper. Available at https://ssrn.com/abstract=2023733.

Grosman, A. and A. Leiponen (2018). 'Organizational transparency and power in firm ownership networks', Journal of Comparative Economics, 46, pp. 1158-1177.

Gu, Y., I. Filatotchev, R. Greg Bell and A. A. Rasheed (2019). 'Liability of foreignness in capital markets: institutional distance and the cost of debt', Journal of Corporate Finance, 57, pp. $142-160$.

Hoskisson, R. E., M. Wright, I. Filatotchev and M. W. Peng (2013). 'Emerging multinationals from mid-range economies: 
the influence of institutions and factor markets', Journal of Management Studies, 50, pp. 1295-1321.

Jelic, R., B. Saadouni and M. Wright (2005). 'Performance of private to public MBOs: the role of venture capital', Journal of Business Finance and Accounting, 32, pp. 643-682.

Judge, W. Q., M. A. Witt, A. Zattoni, T. Talaulicar, J. J. Chen, K. Lewellyn, et al. (2015). 'Corporate governance and IPO underpricing in a cross-national sample: a multilevel knowledgebased view', Strategic Management Journal, 36, pp. 1174-1185.

Karolyi, G. A. (2012). 'Corporate governance, agency problems and international cross-listings: a defense of the bonding hypothesis', Emerging Markets Review, 13, pp. 516-547.

Katelouzou, D. and M. M. Siems (2015). 'Disappearing paradigms in shareholder protection: leximetric evidence for 30 countries, 1990-2013', Journal of Corporate Law Studies, 15, pp. 127-160.

Khanna, T. and K. G. Palepu (2004). 'Globalization and convergence in corporate governance: evidence from Infosys and the Indian software industry', Journal of International Business Studies, 35, pp. 484-507.

Kim, W. and M. S. Weisbach (2008). 'Motivations for public equity offers: an international perspective', Journal of Financial Economics, 87, pp. 281-307.

Knyazeva, A., D. Knyazeva and R. W. Masulis (2013). 'The supply of corporate directors and board independence', The Review of Financial Studies, 26, pp. 1561-1605.

La Porta, R., F. Lopez-de-Silanes and A. Shleifer (2008). 'The economic consequences of legal origins', Journal of Economic Literature, 46, pp. 285-332.

La Porta, R., F. Lopez-de-Silanes, A. Shleifer and R. W. Vishny (1998). 'Law and Finance', Journal of Political Economy, 106, pp. 1113-1155.

Licht, A. N. (2003). 'Cross-listing and corporate governance: bonding or avoiding?', Chicago Journal of International Law, 4, pp. 122-141.

Licht, A. N. and R. B. Adams (2019). 'Shareholders and stakeholders around the world: the role of values, culture, and law in directors' decisions', ECGI Law Working Paper 459.

Meuleman, M., M. Jääskeläinen, M. V. Maula and M. Wright (2017). 'Venturing into the unknown with strangers: substitutes of relational embeddedness in cross-border partner selection in venture capital syndicates', Journal of Business Venturing, 32, pp. 131-144.

Milhaupt, C. J. and K. Pistor (2008). Law and Capitalism: What Corporate Crises Reveal about Legal Systems and Economic
Development Around the World. Chicago, IL: Chicago University Press.

Moore, M. and M. Petrin (2017). Corporate Governance: Law, Regulation and Theory. London: Red Globe Press.

Nelken, D. (2016). 'Comparative legal research and legal culture: facts, approaches, and values', Annual Review of Law and Social Science, 12, pp. 45-62.

Petrin, M. (2016). 'Regulatory analysis in corporate law', The Modern Law Review, 79, pp. 537-574.

Pierre, G. and S. Scarpetta (2006). 'Employment protection: do firms' perceptions match with legislation?', Economics Letters, 90, pp. 328-334.

Pinegar, J. M. and R. Ravichandran (2010). 'Raising capital in emerging markets with restricted global depositary receipts', Journal of Corporate Finance, 16, pp. 622-636.

Roodman, D. (2009). 'How to do xtabond2: an introduction to difference and system GMM in Stata', The Stata Journal, 9, pp. 86-136.

Schnyder, G., R. V. Aguilera and M.M. Siems (2018). 'Twenty years of "law and finance": time to take law seriously', SocioEconomic Review. DOI:10.1093/ser/mwy041.

Siegel, J. (2005). 'Can foreign firms bond themselves effectively by submitting to U.S. law?', Journal of Financial Economics, 75, pp. 319-360.

Stulz, R. (1999). 'Globalization, corporate finance, and the cost of capital', Journal of Applied Corporate Finance, 12, pp. 8-25.

Westphal, J. D. and E. J. Zajac (1994). Substance and symbolism in CEOs' long-term incentive plans. Administrative Science Quarterly, 39, pp. 367-390. https://doi.org/10.5465/AMBPP. 1993.10316996.

Wood, G. and D. M. Wright (2013). 'An age of corporate governance failure? Financialization and its limits'. In M. Wright, D. Siegel and K. Keasey (eds), The Oxford Handbook of Corporate Governance. Oxford: Oxford University Press, pp. 703718.

Wood, G. and M. Wright (2015). 'Corporations and new statism: trends and research priorities', The Academy of Management Perspectives, 29, pp. 271-286.

Wood, G., P. H. Phan and M. Wright (2018). 'The problems with theory and new challenges in theorizing', Academy of Management Perspectives, 32, pp. 405-411.

World Economic Forum (2018). Global Competitiveness Index, available at http://reports.weforum.org/globalcompetitiveness-index/

Gerhard Schnyder (PhD, University of Lausanne, Switzerland) is Professor of International Management and Political Economy at Loughborough University London and a Research Associate at the Centre for Business Research, University of Cambridge. His current work focuses on state-business relations and the political economy of populism, in particular in emerging market contexts. His recent work has been published in Organization Studies, Business \& Society, New Political Economy, Journal of International Management and Global Strategy Journal, among others.

Anna Grosman (PhD, Imperial College, UK) is a Senior Lecturer (eqv. Associate Professor) in Innovation and Entrepreneurship at Loughborough University London. Her research falls at the intersection of corporate governance, corporate finance and international business, with a special emphasis on contemporary state capitalism and corporate governance issues of state-affiliated organizations, such as corporate political ties, board independence and board effectiveness. 
Kun $\mathrm{Fu}(\mathrm{PhD}$, Bocconi University, Italy) is a Senior Lecturer (eqv. Associate Professor) of Innovation and Entrepreneurship at Loughborough University London. Her research interests lie in the fields of strategic entrepreneurship and technology innovation. Her research tries to develop better understanding of how entrepreneurial firms react to their contexts and examines the outcomes of this process such as firm creation, growth, technology innovation and diversification. Some of her research has been sponsored by the British Academy, the Leverhulme Trust and the Sino-British Fellowship Trust.

Mathias Siems (PhD, LMU Munich, Germany) is Professor of Private Law and Market Regulation at the European University Institute (EUI) in Florence, Italy. He is on special leave from Durham University, UK, where he has been Professor of Commercial Law since 2011. Previously, he was a professor at the University of East Anglia, a reader at the University of Edinburgh, an associate professor at the Riga Graduate School of Law, a Fulbright Scholar at Harvard Law School and a Jean Monnet Fellow at the EUI.

Ruth V. Aguilera (PhD, Harvard University, USA) is the Distinguished Darla and Frederick Brodsky Trustee Professor in Global Business at the D'Amore-McKim School of Business, Northeastern University and a Visiting Professor at ESADE Business School. She is interested in research at the intersection of strategic organization and international business, with a focus on comparative corporate governance and corporate social responsibility.

\section{Supporting Information}

Additional supporting information may be found online in the Supporting Information section at the end of the article.

Figure A1: The moderating effects of founder-manager on IPO return when legal perception is negative and positive

Figure A2: The moderating effects of board size on IPO return when legal perception is negative and positive

Figure A3: The moderating effects of independent director on IPO return when legal perception is negative and positive

Figure A4: The moderating effects of women director on IPO return when legal perception is negative and positive

Figure A5: The moderating effects of VC/PE ownership on IPO return when legal perception is negative and positive

Figure A6: The moderating effects of committees on IPO return when legal perception is negative and positive 